\title{
Tailoring Ca-based Nanoparticles by Polyol Process for use as Nematicidals and pH Adjusters in Agriculture
}

P. Tryfon ${ }^{a}$, O. Antonoglou ${ }^{a}$, G. Vourlias ${ }^{b}$, S. Mourdikoudis ${ }^{c, d}$, O. Menkisoglou ${ }^{e}$, C. DendrinouSamara $^{a^{*}}$

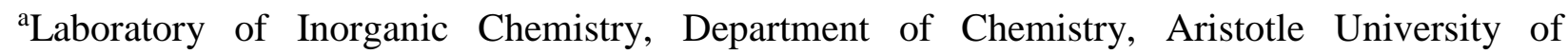
Thessaloniki, 54124 Thessaloniki, Greece.

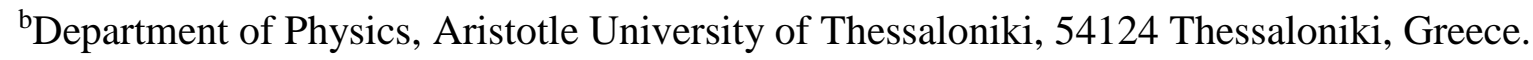

${ }^{c}$ UCL Healthcare Biomagnetic and Nanomaterials Laboratories, London, UK.

${ }^{\mathrm{d} B i o p h y s i c s ~ G r o u p, ~ D e p a r t m e n t ~ o f ~ P h y s i c s ~ a n d ~ A s t r o n o m y, ~ U n i v e r s i t y ~ C o l l e g e ~ L o n d o n ~(U C L), ~}$ London, UK.

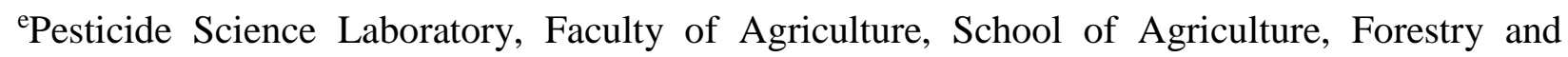
Environment, Aristotle University of Thessaloniki, 54124, Thessaloniki, Greece.

${ }^{*}$ Corresponding author

E-mail address: samkat@ chem.auth.gr 


\section{KEYWORDS:}

Calcium

Calcium hydroxide

Calcium carbonate

Microwave irradiation

Plant protection

Nanofertilizer

Meloidogyne incognita

Meloidogyne javanica 


\begin{abstract}
The remarkable progress in nanotechnology has extended the application of inorganic nanoparticles (NPs) in the agriculture sector, as both economically sustainable and environmentally sound alternatives. Root knot nematodes are undoubtedly a foremost problem of agriculture and research strives to develop effective materials to tackle this issue. Herein, the microwave-assisted selective polyol synthesis of different compositions of $\mathrm{Ca}$ based NPs, $\mathrm{Ca}(\mathrm{OH})_{2}, \mathrm{Ca}(\mathrm{OH})_{2} / \mathrm{CaCO}_{3}$ and $\mathrm{CaCO}_{3}$ is reported and the products were evaluated as nematicides and $\mathrm{pH}$ adjusters. Two precursors $\left(\mathrm{CaCl}_{2}\right.$ and $\left.\mathrm{Ca}\left(\mathrm{NO}_{3}\right)_{2}\right)$ and three polyols (1,2-propylene glycol (PG), tetraethylene glycol (TEG), polyethylene glycol (PEG 8000)) that differ in their red/ox potential have been utilized to provide selectivity over composition. Based on the utilized polyols, NPs are produced as inorganic/organic hybrid formulations with a biocompatible organic coating that provides increased colloidal stability and controlled release of active components. Characterization of NPs has been carried out by XRD, TGA, FTIR, TEM and pH-metry. Each composition exhibited different pH changing ability, an essential feature for agrochemical applications. The in vitro nematicidal activity of $\mathrm{Ca}(\mathrm{OH})_{2}, \mathrm{Ca}(\mathrm{OH})_{2} / \mathrm{CaCO}_{3}$ and $\mathrm{CaCO}_{3}$ NPs was evaluated on second stage juveniles (J2) of two Meloidogyne species (Meloidogyne incognita \& Meloidogyne javanica) based on nematode paralysis experiments. Results unveiled nematicidal activity for all evaluated Ca-based NPs, while $\mathrm{Ca}(\mathrm{OH})_{2}$ and $\mathrm{CaCO}_{3} \mathrm{NPs}$ appeared to be the most and the least effective one, respectively. The nematicidal effect appears to be boosted by the release of $[\mathrm{OH}]^{-}$anions, as indicated by $\mathrm{pH}-$ metric measurements, displaying the crucial role of $[\mathrm{OH}]^{-}$anions in their nematicidal activity.
\end{abstract}




\section{Introduction}

Inorganic nanoparticles (NPs) such as metal and metal oxide based NPs have demonstrated to be efficient for bioapplications including medicine, microbiology and agriculture. ${ }^{1}$ Specifically, nanoagrochemicals can be designed as inorganic/organic hybrid formulations with biocompatible organic coatings, resulting in high bioavailability, controlled release kinetics, decreased amount of active compounds and minimal loss of nutrients. ${ }^{2}$ Nanoagrochemicals can emerge as multimodal agents acting as both fertilizers and pesticides/fungicides confronting the presence of phyto-parasites and phyto-pathogenic microorganisms leading to enhanced plant growth, protection and optimal water and nutrient management. ${ }^{3,4}$ In fact, it is expected that the number of products involving nanotechnology in agricultural applications will increase in the near future. ${ }^{5}$

Plant-parasitic nematodes are one of the most notorious crop pests associated with the most economical important cultures with global annual agricultural losses estimating to exceed US $\$ 100$ billion. ${ }^{6}$ Among them, Root Knot Nematodes (RKN) (Meloidogyne spp.), have been ranked at the top of the list of 10 most important genera of parasitic nematodes. ${ }^{7}$ Meloidogyne spp. with Meloidogyne incognita and Meloidogyne javanica infect most of the cultivated crops, have a wide host range, show a global distribution and cause severe damage to most solanaceous crops worldwide. ${ }^{6,7}$ The second-stage larvae (J2) initiates the formation of giant cells as root galls that drastically limit water and nutrient uptake on crop plants leading to several symptoms, included roots deformation, malnutrition, chlorosis, stunted growth, wilting as secondary interaction with other phytopathogens. ${ }^{68,}{ }^{69}$ Phyto-nematode control is achieved mainly with cultural practices, crop rotation, and resistant cultivars, combined with a few available chemical nematicides that are still authorized. Synthetic pesticides such as carbamate, organophosphate, and organophthalide formulations have been used in the past as chemical nematicides but most of them are restricted due to adverse environmental footprint and health effects. ${ }^{70}$ Therefore, the development of alternative and environmentally friendly nematode management strategies is mandatory, creating a significant market opportunity for alternative products such as nanonematicides. ${ }^{7,8,9}$ Several nanoparticle systems have been applied against free living nematodes. More specifically, ZnO NPs studied against Caenorhabditis elegans displayed $\mathrm{EC}_{50}$ (half maximal effective concentration) of $635 \mu \mathrm{g} / \mathrm{mL}$ in vitro ${ }^{10}$ 
while in a recent study, $\mathrm{LC}_{50}$ (half maximal lethal concentration) recorded from 620 to $1000 \mathrm{ppm}$ depending on NPs size. ${ }^{11}$ Moreover, $\mathrm{Al}_{2} \mathrm{O}_{3}\left(\mathrm{LC}_{50 / 24 \mathrm{~h}}=82 \mathrm{mg} / \mathrm{L}\right)$ and $\mathrm{TiO}_{2}\left(\mathrm{LC}_{50 / 24 \mathrm{~h}}=136 \mathrm{mg} / \mathrm{L}\right)$ NPs were shown to inhibit growth and the reproductive capability of the C. elegans comparing with bulk. ${ }^{12}$ Additionally, exposure of $\mathrm{J} 2 \mathrm{M}$. incognita to Ag NPs (30 to $150 \mu \mathrm{g} / \mathrm{ml}$ ) led to $>99 \%$ nematodes immobilization in $6 \mathrm{~h}^{13}$

Calcium is an important material with several applications in heritage conservation, ${ }^{35}$ dentistry ${ }^{36}$ and civil construction. ${ }^{37}$ Additionaly, is an important determinant for plant salt tolerance and plays an essential role in processes related to plant viability. ${ }^{14,15}$ Plants grown under calcium deficient conditions are more susceptible to plant pathogens and show reduced growth of apical meristems, chlorotic leaves, and cell wall breakdown leading to softening of tissues. ${ }^{16}$ In the agricultural field, the two main calcium amendments are $\mathrm{CaCO}_{3}$ (limestone) and $\mathrm{Ca}(\mathrm{OH})_{2}$ (hydrated lime). Liming materials are generally considered benign and beneficial when used to improve the soil $\mathrm{pH}$, while each material exhibits diverse $\mathrm{pH}$ values and demonstrates a variety of functions. $\mathrm{Ca}(\mathrm{OH})_{2}$ affects rapidly $\mathrm{pH}$, is unstable and may eventually revert to insoluble forms while $\mathrm{CaCO}_{3}$ is more stable. ${ }^{17}$ Till now nanoformulations of limes in agricultural applications are limited while most of them refer to fertilization processes $;{ }^{18}$ 'Naked' $\mathrm{CaCO}_{3}$ NPs of 20-80 $\mathrm{nm}$ have been used as fertilizers at a concentration of $160 \mathrm{mg} / \mathrm{L}$ to peanut (Arachis hypogaea) seedlings grown in sand (15\% increase of dry biomass weight); $\mathrm{CaCO}_{3} \mathrm{NPs}$ and humic acids $(1000 \mathrm{mg} / \mathrm{L})$ when performed together, achieved the maximum seedling growth (30\% increase over that for the control and a $14 \%$ over that for the $\mathrm{CaCO}_{3} \mathrm{NPs}$ alone); $\mathrm{CaCO}_{3} \mathrm{NPs}$ treatments were better at increasing $\mathrm{Ca}$ content when sprayed on Tankan (Citrus tankan) leaves; application of $\mathrm{CaCO}_{3} \mathrm{NPs}(60 \mathrm{~nm})$ appeared better in terms of protection efficacy against oviposition punctures from Oriental fruit flies on the Indian jujube (Zizyphus mauritiana). ${ }^{19}$ Meanwhile, Ca-based NPs are emerging as pesticides as well as antibacterial candidates against gram negative (Escherichia coli, Pseudomonas aeruginosa, Salmonella typhi, Shigella flexneri, Klebsiella pneumonia, Proteus vulgaris, Proteus mirabilis) and gram positive (Bacillus subtilis, Streptococcus aureus, Micrococcus luteus, ) bacteria. ${ }^{20-21}$

Herein, in continuation of our research on inorganic/organic hybrid NPs, potential bioapplications and nematicidal agents ${ }^{22-29}$ the synthesis and nematicidal activity evaluation of Ca-based NPs with diverse compositions such as $\mathrm{Ca}(\mathrm{OH})_{2}, \mathrm{Ca}(\mathrm{OH})_{2} / \mathrm{CaCO}_{3}$ and $\mathrm{CaCO}_{3} \mathrm{NPs}$, is reported. To the best of our knowledge, this is the first report of Ca-based NPs as nematicidals. The goal of the current study is to develop a simple 
synthetic protocol for the selective synthesis of diverse Ca-based NPs of small nanosizes, high crystallinity and yield to model further these structures as nematicidals. For that purpose, a microwave-assisted modified polyol process has been chosen as a green and simple route that is much faster, cheaper and energy efficient compared with conventional heating ovens and leads to high crystalline small nanoparticles. ${ }^{27,38}$ With a need of utilizing NPs as an all set formulation product, synthesis in polyols display multiple advantages such as one step fabrication of hydrophilic, eco-friendly and stable products with biocompatible stable organic coatings. The mechanistic representation of the polyol process is still in the build, polyols participate in red/ox, complexation and decomposition reactions with the cations and anions of the solution and form intermediates before yielding nanoparticles. ${ }^{26,27,39-46}$ The products of the red/ox reactions are oxidized derivatives of polyols, like glycolaldehyde, glycoxylic acid, glycolic acid, oxalic acid, oxalates and $\mathrm{CO}_{2}$. Moreover, it has been shown by us and others that polyols of higher reductive ability and cations/anions of higher oxidizing activity react in situ with polyols favoring the oxidation pathway while increasing the effectiveness of polyols as carbon sources. ${ }^{26,27,39,41,44-46}$ On that basis, polyols of different physicochemical properties such as 1,2-propylene glycol (PG), tetraethylene glycol (TEG) \& polyethylene glycol (PEG 8000) and calcium precursors of dissimilar red/ox potential and activity $\left.\left(\mathrm{CaCl}_{2} \& \mathrm{Ca}_{(} \mathrm{NO}_{3}\right)_{2}\right)$, have been utilized. ${ }^{26,27,46}$ The in vitro nematicidal activity of NPs was evaluated on two second stage juveniles (J2) Meloidogyne species, (Meloidogyne incognita, Meloidogyne javanica) based on 96 well-plate bioassays relating to nematode mobility. The time-dependent stability of Ca-based NPs and $\mathrm{EC}_{50}$ (Half maximal effective concentration) values were examined for 24, 42, 74 and $96 \mathrm{hr}$ through ANOVA statistics analysis and using probit values. The physicochemical properties of each structure lead to dissimilar $\mathrm{pH}$ adjusting and nematicidal activities while in the case of $\mathrm{Ca}(\mathrm{OH})_{2} / \mathrm{CaCO}_{3} \mathrm{NPs}$ synergistic effects have arisen.

\section{Materials and methods}


All the reagents were of analytical grade and were used without any further purification: $\mathrm{CaCl}_{2}(\mathrm{Laboratory}$ (BDH), $\mathrm{M}=110,99 \mathrm{~g} / \mathrm{mol}$ ), $\mathrm{Ca}\left(\mathrm{NO}_{3}\right)_{2} \cdot 4 \mathrm{H}_{2} \mathrm{O}$ (May and Baker LtD, $\mathrm{M}=236 \mathrm{~g} / \mathrm{mol}$ ), polyethylene glycol 8000, PEG 8000 (Alfa Aesar), tetraethylene glycol, TEG (Sigma-Aldrich $\geq 99 \%$, M

\subsection{Synthesis of Polyol coated Ca-based NPs}

A microwave assisted polyol process (MW-PP) was chosen as the Ca-based NPs synthetic route. A commercial microwave accelerated reaction system (MARS 6-240/50-CEM) running at a maximum frequency of $2450 \mathrm{MHz}$ and a power of $1800 \mathrm{~W}$, was utilized. ${ }^{27}$ Samples synthesized using chloride precursors will be assigned as $\mathrm{CaC}$ while samples synthesized using nitrate precursors will be assigned as CaN. General procedure for sample CaC PEG, $\mathrm{CaCl}_{2}(0.8 \mathrm{gr}, 7.21 \mathrm{mmol})$ and PEG 8000 (7.5 gr into 22.5 $\mathrm{ml} \mathrm{H}_{2} \mathrm{O}$ ) were mixed and dissolved, then $10 \mathrm{ml}$ of aquatic solution of $\mathrm{NaOH}(1.5 \mathrm{M})$ was added drop by drop though continuous stirring, followed by transferring to an autoclave. The reaction was carried out at $150{ }^{\circ} \mathrm{C}$ with a hold time of $30 \mathrm{~min}$ and a ramp time heating step (from 25 to $150{ }^{\circ} \mathrm{C}$ ) set at $15 \mathrm{~min}$. After MW-PP, the autoclave was cooled naturally to room temperature and after centrifugation at $5000 \mathrm{rpm}$ for $20 \mathrm{~min}$, the supernatant liquids were discarded, and a white precipitate was acquired and washed three times with ethanol, for the isolation of unreacted precursors. An excess of polyol was utilized in each sample preparation. Total amount of solvent was kept constant at $40 \mathrm{ml}$. Specifically, for the remaining samples: CaN PEG: $\mathrm{Ca}\left(\mathrm{NO}_{3}\right)_{2} .4 \mathrm{H}_{2} \mathrm{O}(1.7 \mathrm{gr}, 7.21 \mathrm{mmol})$, polyethylene glycol, PEG 8000 (7.5 gr into $22.5 \mathrm{ml} \mathrm{H}_{2} \mathrm{O}$ ), $10 \mathrm{ml} \mathrm{NaOH}(1.5 \mathrm{M})$.

CaC TEG: $\mathrm{CaCl}_{2}(0.8 \mathrm{gr}, 7.21 \mathrm{mmol})$, tetraethylene glycol, TEG $(30 \mathrm{ml}), 10 \mathrm{ml} \mathrm{NaOH}(1.5 \mathrm{M})$.

CaN TEG: $\mathrm{Ca}\left(\mathrm{NO}_{3}\right)_{2} .4 \mathrm{H}_{2} \mathrm{O}(1.7 \mathrm{gr}, 7.21 \mathrm{mmol})$, tetraethylene glycol, TEG $(30 \mathrm{ml}), 10 \mathrm{ml} \mathrm{NaOH}(1.5 \mathrm{M})$. CaC PG: $\mathrm{CaCl}_{2}(0.8$ gr, $7.21 \mathrm{mmol})$, 1,2-propylene glycol, PG $(30 \mathrm{ml}), 10 \mathrm{ml} \mathrm{NaOH}(1.5 \mathrm{M})$. CaN PG: $\mathrm{Ca}\left(\mathrm{NO}_{3}\right)_{2} \cdot 4 \mathrm{H}_{2} \mathrm{O}(1.7 \mathrm{gr}, 7.21 \mathrm{mmol})$, 1,2-propylene glycol, $\mathrm{PG}(30 \mathrm{ml}), 10 \mathrm{ml} \mathrm{NaOH}(1.5 \mathrm{M})$.

\subsection{Characterization of Ca-based NPs}


X-Ray powder diffraction graphs (XRD) were recorded at Bragg-Brentano (BB) geometry using a two-cycles Rigaku Ultima+ powder X-ray diffractometer with a $\mathrm{Cu}$ Ka radiation operating at $40 \mathrm{kV} / 30 \mathrm{~mA}$. Thermogravimetric analysis (TGA) was employed using SETA-RAM SetSys-1200 and carried out in the range from room temperature to $900{ }^{\circ} \mathrm{C}$ at a heating rate of $10{ }^{\circ} \mathrm{C} / \mathrm{min}$ under nitrogen atmosphere. Fourier transform infrared spectra (FTIR) $\left(400-4000 \mathrm{~cm}^{-1}\right)$ were recorded using a Nicolet FT-IR 6700 spectrometer with samples prepared as $\mathrm{KBr}$ pellets. UV/Vis spectra were recorded with a Hitachi U-2001 double-beam UV/Vis spectrophotometer. Dynamic light scattering (DLS) and $\zeta$-potential measurements were carried out at $25^{\circ} \mathrm{C}$ utilizing a Nano ZS Malvern apparatus. pH-metry was done in MQ water via a Mettler Toledo $\mathrm{pH}$ meter. Conventional Transmission Electron Microscopy (TEM) images were obtained with a JEOL JEM 1200-EX transmission electron microscope operated at an acceleration voltage of $120 \mathrm{kV}$. For TEM observations we have used suspensions of the nanoparticles deposited onto carbon-coated copper grids.

\subsection{Nematode Motility Bioassays}

Nematode Cultures. The nematicidal activity of Ca-based NPs was tested in terms of paralysis against M. incognita and M. javanica second-stage juveniles (J2). Nematodes population were originally sampled from naturally infested tomato greenhouses in Heraklion, Crete and reared on tomato (Solanum lycopersicum L.) cv. Belladonna, a susceptible cultivation to root-knot nematodes. All nematodes J2 which were hatched in the first 3 days were discarded, and thereafter freshly hatched $(24 \mathrm{~h})$ second-stage juveniles (J2) were collected used for the bioassays according to Ntalli et al. ${ }^{30,31}$

Paralysis Activity of Ca-based NPs

The activity of Ca-based NPs solutions $\left(\mathrm{Ca}(\mathrm{OH})_{2}, \mathrm{Ca}(\mathrm{OH})_{2} / \mathrm{CaCO}_{3}\right.$ and $\left.\mathrm{CaCO}_{3}\right)$ against $\mathrm{J} 2$ of $M$. incognita and M. javanica in paralysis tests was measured at concentrations of 50, 100, 200, 300, 400, 500, $600,1000 \mu \mathrm{g} / \mathrm{ml}$ and $\mathrm{CaCl}_{2}$ was tested at concentrations up to $800 \mathrm{mg} / \mathrm{ml}$. The assays were performed in Cellstar 96-well plates (Greiner bio-one), using 20-25 J2 per treatment well and treatments were organized in a complete randomised design according to Ntalli et al. ${ }^{28,30} \mathrm{Ca}$-based NPs and $\mathrm{CaCl}_{2}$ were dispersed in water, dissolved using a vortex mixer and sonicator before transfering into the culture plates. J2 suspensions were mixed in 96-well culture plates at a ratio of 1:1 v/v. Distilled water, served as control. The plates were 
covered to prevent evaporation and were maintained in the dark at $27^{\circ} \mathrm{C}$ in an incubator. Border wells containing water with nematodes were placed around the wells of each treatment checking the vapour drift among wells to avoid a possible interfere with the efficacy results. Juveniles motility was assessed using an inverted microscope (Euromex, The Netherlands) at 40× magnification after 24, 48, 72 and 96 hours and were ranked into two distinct categories: motile or paralysed ${ }^{30}$ to calculate $\mathrm{EC}_{50}$ values.

\subsection{Statistical analysis}

Treatments of the paralysis experiments were replicated six times, and each experiment was performed twice. The percentages of paralysed $\mathrm{J} 2$ in the microwell assays were corrected by removal of the natural death/paralysis percentage in the water control, according to the Schneider Orelli formula ${ }^{33}$ and they were analysed (ANOVA) after being combined over time:

Corrected $\%=[($ paralysis $\%$ in treatment - paralysis $\%$ in control $) /(100-$ paralysis $\%$ in control $)] \times 100$

ANOVA indicated no significant difference in time measurements. Corrected percentages of paralyzed J2 treated with test compounds were subjected to probit linear regression analysis for $\mathrm{EC}_{50}$ calculation. The mean value of the six replicates per test concentration and immersion period was used to calculate the $\mathrm{EC}_{50}$ value. Statistical analysis was performed using IBM SPSS Statistics program, in order to determine the effect of the different doses of the NPs after 24, 48, 72 and 96 hours. The dose - response curves were created using the program Origin Pro 8 (Graphing and Analysis).

\section{Results and discussion}

\subsection{Synthesis and characterization of Ca-based NPs}


Figure 1 illustrates the X-ray diffractograms (XRD) of all synthesized Ca-based NPs. Samples are labeled as $\mathrm{CaN}$ and $\mathrm{CaC}$ for syntheses starting with the $\mathrm{Ca}\left(\mathrm{NO}_{3}\right)_{2}$ and $\mathrm{CaCl}_{2}$ precursors, respectively. NPs are grouped based on the utilized polyol, PEG (Fig. 1A), TEG (Fig. 1B) and PG (Fig. 1C). In presence of PEG (Fig.1A), both precursors yielded hexagonal $\mathrm{Ca}(\mathrm{OH})_{2} \mathrm{NPs}$ as indicated by the reflections that correspond to the (001), (100), (101), (102), (110), (111), (201), (103) and (202) planes of $\mathrm{Ca}(\mathrm{OH})_{2}$ portlandite phase (JCPDS no. 44-1481). No other peaks were present in the diffractogram verifying the purity of $\mathrm{Ca}(\mathrm{OH})_{2}$ crystallite. In contrast, synthesis in the presence of TEG in both precursors resulted in the appearance of a second phase in the diffractogram (Fig.1B), matching the reflections of the rhombohedral calcite phase, $\mathrm{CaCO}_{3}$ (JCPDS no. 72-3917). Both materials produced in TEG (CaN TEG and CaC TEG, Fig.1B) are $\mathrm{Ca}(\mathrm{OH})_{2} / \mathrm{CaCO}_{3}$ mixtures. Interestingly this is not the case for the even more reductive PG (188 ${ }^{\circ} \mathrm{C}$ boiling point). While sample $\mathrm{CaC}$ PG synthesized from the chloride precursor is a mixture of $\mathrm{Ca}(\mathrm{OH})_{2} / \mathrm{CaCO}_{3}$ crystallites (Fig.1C), the reaction of $\mathrm{PG}$ with the nitrate precursor produces the sole phase of $\mathrm{CaCO}_{3}(\mathrm{CaN}$ PG, Fig.1C). The crystallite size of all phases in all samples was calculated from the Scherrer formula, the $\mathrm{D}=0.891 \lambda / \beta \cos \theta$, and full - width at half-maximum of the main peak of each crystallite phase, $\mathrm{Ca}(\mathrm{OH})_{2}$ and $\mathrm{CaCO}_{3}$. Calculated sizes are 40 and $43 \mathrm{~nm}$ for the $\mathrm{Ca}(\mathrm{OH})_{2}$ phase of $\mathrm{CaC}$ PEG and CaN PEG, respectively, 23/31, 30/39 and 23/41 nm for the $\mathrm{Ca}(\mathrm{OH})_{2} / \mathrm{CaCO}_{3}$ mixture of $\mathrm{CaC} \mathrm{TEG}$, CaN TEG and $\mathrm{CaC}$ PG, respectively and $64 \mathrm{~nm}$ for the $\mathrm{CaCO}_{3}$ phase of $\mathrm{CaN}$ PG.

$\mathrm{Ca}^{2+}$ ions rapidly react with $\left[\mathrm{OH}^{-}\right]$to form $\mathrm{Ca}(\mathrm{OH})_{2} \mathrm{NPs}$ while the $\mathrm{CaCO}_{3}$ structure arises from polyol red/ox reaction products. The products of the red/ox reactions are oxidized derivatives of polyols, like glycolaldehyde, glycoxylic acid, glycolic acid, oxalic acid, oxalates and $\mathrm{CO}_{2}$. The reductive ability of the polyol mainly depends on its boiling point, lower boiling points correlate to higher reductive ability, as shown before by us and others. ${ }^{26,27,46}$ TEG has a lower boiling point than PEG, $314{ }^{\circ} \mathrm{C}$ and $>350{ }^{\circ} \mathrm{C}$, respectively. Therefore, the oxidation polyol pathway is more favored in TEG resulting in the production of $\mathrm{CO}_{2}$ inside the autoclave. $\mathrm{CO}_{2}$ is dissolved in the polyol, is transformed in carbonate anions that react with calcium cations to give calcium carbonate, $\mathrm{CaCO}_{3}$, according to equation (1):47

$$
\mathrm{CO}_{2 \text { (dissolved) }} \rightarrow \mathrm{H}_{2} \mathrm{CO}_{3} \rightarrow \mathrm{H}^{+}+\mathrm{HCO}_{3}{ }^{-} \rightarrow \mathrm{CO}_{3}{ }^{2-}+\mathrm{Ca}^{2+} \rightarrow \mathrm{CaCO}_{3}(1)
$$


As polyols react with the anions in the solution, the $\mathrm{NO}^{3-}$ anion is a much stronger oxidizing agent than $\mathrm{Cl}^{-}$ .${ }^{39}$ Consequently, combining the most reductive polyol, $\mathrm{PG}$, with the most oxidizing anion, $\mathrm{NO}_{3}{ }^{-}$, results in strong carbonation of PG and yields pure $\mathrm{CaCO}_{3} \mathrm{NPs}$.

From recent studies, Ca-based NPs have been synthesized as $\mathrm{Ca}(\mathrm{OH})_{2}$ with crystallite size of $30-100 \mathrm{~nm}$ and as $\mathrm{CaCO}_{3}$ with crystallite size of $25-50 \mathrm{~nm} \cdot{ }^{20,48-50} \mathrm{Ca}$-based NPs synthesized in the current work using a microwave assisted polyol process are of the smallest reported sizes and in the desired size range. Additionally, $\mathrm{Ca}(\mathrm{OH})_{2} / \mathrm{CaCO}_{3}$ samples display a common trend regarding their crystallite size. $\mathrm{As}^{\mathrm{CaCO}_{3}}$ is formed, the size of the $\mathrm{Ca}(\mathrm{OH})_{2}$ is reduced while the size of $\mathrm{CaCO}_{3}$ increases as well as the overall size $\cong 60 \mathrm{~nm}$. This implies that, apart from the $\mathrm{CaCO}_{3}$ phase formation via eq(1), $\mathrm{Ca}(\mathrm{OH})_{2}$ can partially transform in the $\mathrm{CaCO}_{3}$ phase. ${ }^{47}$ Moreover, the main peak of $\mathrm{CaCO}_{3}$ around $29-30^{\circ}$ is shifted to the left as the $\mathrm{CaCO}_{3}$ content increases and is clearly right-shifted from the peak of the pure $\mathrm{CaCO}_{3}(\mathrm{CaN} \mathrm{PG}$ sample), as seen in Fig. S1 (SI). This suggests that $\mathrm{CaCO}_{3}$ is formed as an outer shell. ${ }^{61}$ 

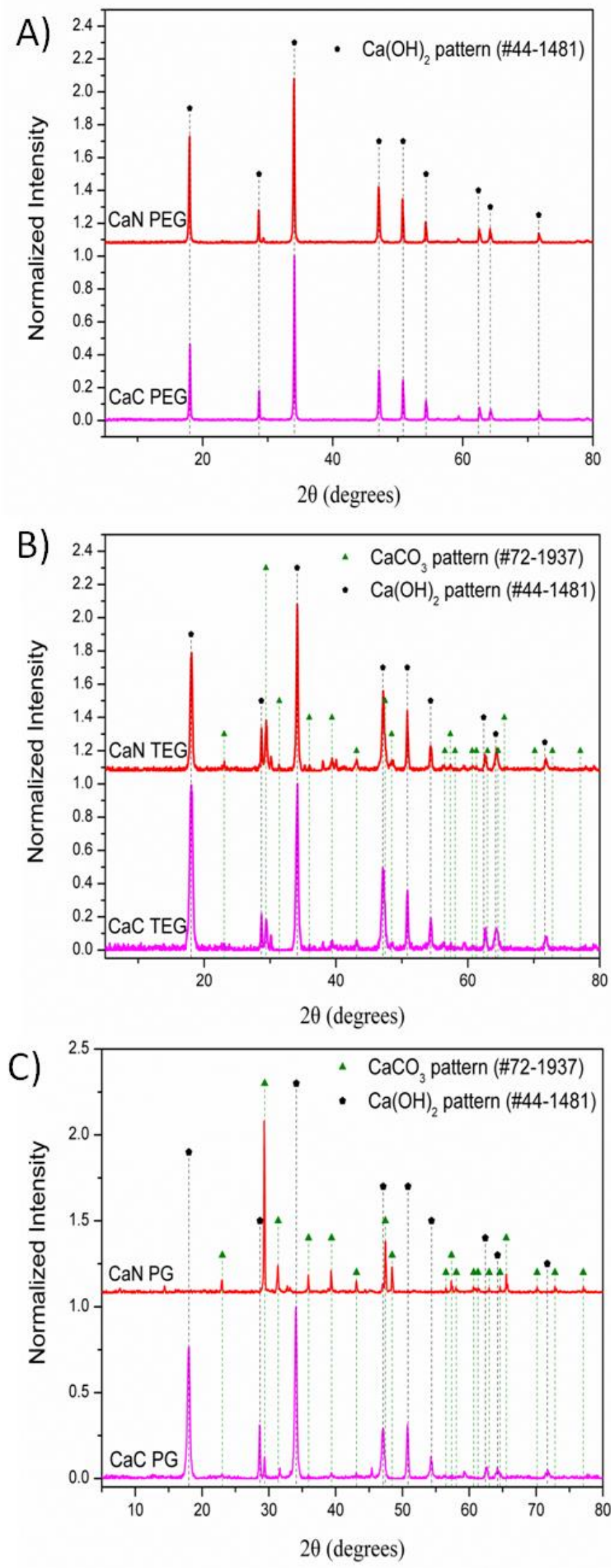
Figure 1. X-ray diffractograms (XRD) of Ca-based NPs synthesized with PEG (A), TEG (B) and PG (C), with $\mathrm{CaCl}_{2}(\mathrm{CaC})$ and $\mathrm{Ca}\left(\mathrm{NO}_{3}\right)_{2}(\mathrm{CaN})$ as precursors.

Thermogravimetric analysis (TGA) was employed to provide the composition and $\% \mathrm{w} / \mathrm{w}$ content for the as-produced NPs. TGA enables a composition analysis for Ca-based NPs as the decomposition of $\mathrm{Ca}(\mathrm{OH})_{2}$ and $\mathrm{CaCO}_{3}$ structures takes place in different temperatures according to equations (2) and (3): ${ }^{35}$, 62

$$
\begin{aligned}
\mathrm{Ca}(\mathrm{OH})_{2} & \rightarrow \mathrm{CaO}+\mathrm{H}_{2} \mathrm{O}\left(400-600{ }^{\circ} \mathrm{C}\right)(2) \\
\mathrm{CaCO}_{3} & \rightarrow \mathrm{CaO}+\mathrm{CO}_{2}\left(630-800{ }^{\circ} \mathrm{C}\right)(3)
\end{aligned}
$$

Additionally, decomposition of $\mathrm{Ca}(\mathrm{OH})_{2}$ is accompanied by water loss corresponding to $24 \% \mathrm{w} / \mathrm{w}$ of $\mathrm{Ca}(\mathrm{OH})_{2}\left(\mathrm{MW}_{\mathrm{Ca}(\mathrm{OH}) 2}=74, \mathrm{MW}_{\mathrm{H} 2 \mathrm{O}}=18\right)$ while decomposition of $\mathrm{CaCO}_{3}$ is accompanied by carbon dioxide loss corresponding to $44 \% \mathrm{w} / \mathrm{w}$ of $\mathrm{CaCO}_{3}\left(\mathrm{MW}_{\mathrm{CaCO} 3}=100, \mathrm{MW}_{\mathrm{CO} 2}=44\right)$. These values are essential when quantifying different decompositions happening in the same temperature area. This is especially important in the current study, as polyols decompose in the same vicinity as $\mathrm{Ca}(\mathrm{OH})_{2}$, right after $400{ }^{\circ} \mathrm{C} .{ }^{26,27,44-46}$ Moreover, high molecular weight polyols such as PEG form a double layer of coating around the surface of the $\mathrm{NPs}^{46,63}$ that decomposes around the same vicinity as $\mathrm{CaCO}_{3}$, just above $550{ }^{\circ} \mathrm{C}$.

Figure 2 portrays the thermogravimetric curves of the NPs, displaying the weight loss in relation to the temperature $\left(25-850^{\circ} \mathrm{C}\right)$. In all NPs, the thermogravimetric curve is separated into three areas. The weight loss in first area (up to $350^{\circ} \mathrm{C}$ ) is due to the humidity of the NPs, observed in all samples. For $\mathrm{Ca}(\mathrm{OH})_{2}$ NPs synthesized in PEG (Fig. 2A and 2B) the weight loss in second area $\left(350-550{ }^{\circ} \mathrm{C}\right)$ corresponds to the decomposition of both the surfactant and $\mathrm{Ca}(\mathrm{OH})_{2}$. The weight loss in the third area $\left(550-850{ }^{\circ} \mathrm{C}\right)$ is attributed to the double layer of PEG coating on the surface of the $\mathrm{Ca}(\mathrm{OH})_{2} \mathrm{NPs}$. By applying the theoretical loss due to the decomposition of $\mathrm{Ca}(\mathrm{OH})_{2}\left(24 \%\right.$ of the total weight loss, $\left.\mathrm{MW}_{\mathrm{Ca}(\mathrm{OH}) 2}=74, \mathrm{MW}_{\mathrm{H} 2 \mathrm{O}}=18\right)$, the estimated composition of NPs synthesized in PEG is $\left[81.5 \% \mathrm{Ca}(\mathrm{OH})_{2} / 18.5 \%\right.$ PEG] and [79\% $\mathrm{Ca}(\mathrm{OH})_{2} / 21 \%$ PEG] for samples $\mathrm{CaN}$ PEG and $\mathrm{CaC}$ PEG, respectively. For $\mathrm{Ca}(\mathrm{OH})_{2} / \mathrm{CaCO}_{3} \mathrm{NPs}$ synthesized in TEG (Fig.2 C and D) the weight loss in second area $\left(350-630{ }^{\circ} \mathrm{C}\right)$ corresponds to the decomposition of both the surfactant and $\mathrm{Ca}(\mathrm{OH})_{2}$. However, the weight loss in the third area $\left(630-850{ }^{\circ} \mathrm{C}\right)$ 
is not a case of double layer but the decomposition of $\mathrm{CaCO}_{3}$. This is clearly distinct from the decomposition of a double coating layer, happening about $100{ }^{\circ} \mathrm{C}$ earlier (Fig. 2A and 2B). By applying the theoretical loss due to the decomposition of $\mathrm{Ca}(\mathrm{OH})_{2}\left(24 \%\right.$ of the total weight loss, $\left.\mathrm{MW}_{\mathrm{Ca}(\mathrm{OH}) 2}=74, \mathrm{MW}_{\mathrm{H} 2 \mathrm{O}}=18\right)$ and $\mathrm{CaCO}_{3}\left(44 \%\right.$ of the total weight loss $\left.\mathrm{MW}_{\mathrm{CaCO} 3}=100, \mathrm{MW}_{\mathrm{CO} 2}=44\right)$, the estimated composition of NPs synthesized in TEG is $\left[\begin{array}{llll}65.6 \% & \mathrm{Ca}(\mathrm{OH})_{2} / 25.3 \% & \mathrm{CaCO}_{3} / 9.1 \% & \mathrm{TEG}\end{array}\right]$ and $\left[\begin{array}{lll}67.7 \% & \mathrm{Ca}(\mathrm{OH})_{2} / 23.9 \%\end{array}\right.$ $\mathrm{CaCO}_{3} / 8.4 \%$ TEG] for samples CaN TEG and $\mathrm{CaC}$ TEG, respectively. For $\mathrm{CaCO}_{3}$ and $\mathrm{Ca}(\mathrm{OH})_{2} / \mathrm{CaCO}_{3}$ NPs synthesized in PG (Fig. $2 \mathrm{E}$ and $2 \mathrm{~F}$, respectively) the weight loss in second area $\left(350-630{ }^{\circ} \mathrm{C}\right.$ ) corresponds to the decomposition of the surfactant (Fig. 2E) for sample CaN PG and the decomposition of the surfactant and $\mathrm{Ca}(\mathrm{OH})_{2}$ (Fig. $\left.2 \mathrm{~F}\right)$ for sample $\mathrm{CaC} \mathrm{PG}$. The weight loss in the third area $\left(630-850{ }^{\circ} \mathrm{C}\right)$ is attributed to the decomposition of $\mathrm{CaCO}_{3}$. By applying the theoretical loss due to the decomposition of $\mathrm{Ca}(\mathrm{OH})_{2}\left(24 \%\right.$ of the total weight loss, $\left.\mathrm{MW}_{\mathrm{Ca}(\mathrm{OH}) 2}=74, \mathrm{MW}_{\mathrm{H} 2 \mathrm{O}}=18\right)$ and $\mathrm{CaCO}_{3}(44 \%$ of the total weight loss $\left.\mathrm{MW}_{\mathrm{CaCO} 3}=100, \mathrm{MW}_{\mathrm{CO} 2}=44\right)$, the estimated composition of NPs synthesized in PG is $[94.3 \%$ $\left.\mathrm{CaCO}_{3} / 5.7 \% \mathrm{PG}\right]$ and $\left[55.8 \% \mathrm{Ca}(\mathrm{OH})_{2} / 35.6 \% \mathrm{CaCO}_{3} / 8.6 \% \mathrm{PG}\right]$ for samples $\mathrm{CaN} \mathrm{PG}$ and $\mathrm{CaC} \mathrm{PG}$, respectively. 

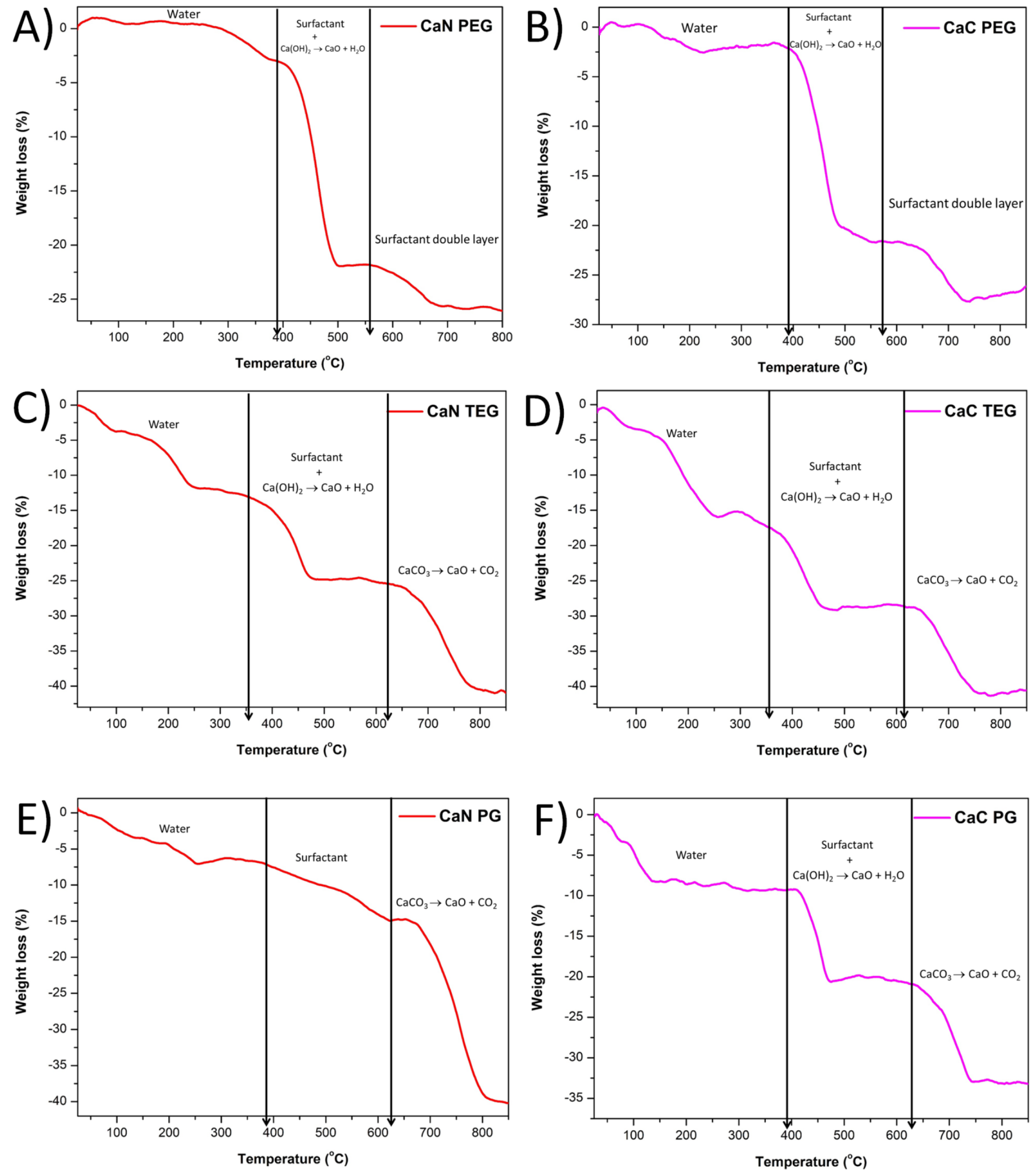
Figure 2. Thermogravimetric analysis (TGA) of Ca-based NPs synthesized with PEG (A \& B), TEG (C \& D) and $\mathrm{PG}(\mathrm{E} \& \mathrm{~F})$, with $\mathrm{CaCl}_{2}(\mathrm{CaC})$ and $\mathrm{Ca}\left(\mathrm{NO}_{3}\right)_{2}(\mathrm{CaN})$ as precursors.

The structural composition and crystallite size of all NPs is given in Table 1. It is clear from the calculated values that the $\% \mathrm{w} / \mathrm{w}$ of the organic polyol coating on the surface of NPs increases in parallel with the molecular weight of the utilized polyol. ${ }^{26}, 46$ In so, PEG provided the highest $\%$ w/w organic coating while PG the lowest. Increase in the MW of polyol leads to a more curl type of coating and in the case of PEG a double layer is formed. ${ }^{46,63}$ Furthermore, the highest $\% \mathrm{w} / \mathrm{w} \mathrm{CaCO}_{3}$ values were calculated for the most reductive $\mathrm{PG}$ and the most oxidative $\mathrm{NO}_{3}{ }^{-}$anion, in agreement with the XRD results and synthetic hypothesis. Fabrication products are given in scheme 1.

Table 1. Characterization of Ca-based NPs synthesized in different polyols and precursors

\begin{tabular}{|c|c|c|c|c|c|c|}
\hline \multirow{2}{*}{$\begin{array}{c}\text { Sample } \\
\text { name }\end{array}$} & \multirow{2}{*}{ Precursor } & \multirow{2}{*}{ Polyol } & \multirow{2}{*}{$\begin{array}{l}d_{X R D} \\
(n m)\end{array}$} & \multicolumn{3}{|c|}{ Structural composition (\%w/w) } \\
\hline & & & & $\mathrm{Ca}(\mathrm{OH})_{2}$ & $\mathrm{CaCO}_{3}$ & Org. coating \\
\hline CaN PEG & $\mathrm{Ca}\left(\mathrm{NO}_{3}\right)_{2}$ & PEG & 43 & 81.5 & 0 & 18.5 \\
\hline CaC PEG & $\mathrm{CaCl}_{2}$ & PEG & 40 & 79 & 0 & 21 \\
\hline CaN TEG & $\mathrm{Ca}\left(\mathrm{NO}_{3}\right)_{2}$ & TEG & $30 / 39$ & 65.6 & 25.3 & 9.1 \\
\hline CaC TEG & $\mathrm{CaCl}_{2}$ & TEG & $23 / 31$ & 67.7 & 23.9 & 8.4 \\
\hline CaN PG & $\mathrm{Ca}\left(\mathrm{NO}_{3}\right)_{2}$ & PG & 64 & 0 & 94.3 & 5.7 \\
\hline CaC PG & $\mathrm{CaCl}_{2}$ & PG & $23 / 41$ & 56 & 35.8 & 8.2 \\
\hline
\end{tabular}


$\begin{array}{lll}\text { (1) } 1,2 \text {-propylene glycol } & \text { (2) tetraethylene glycol } & \text { (3) polyethylene glycol }\end{array}$

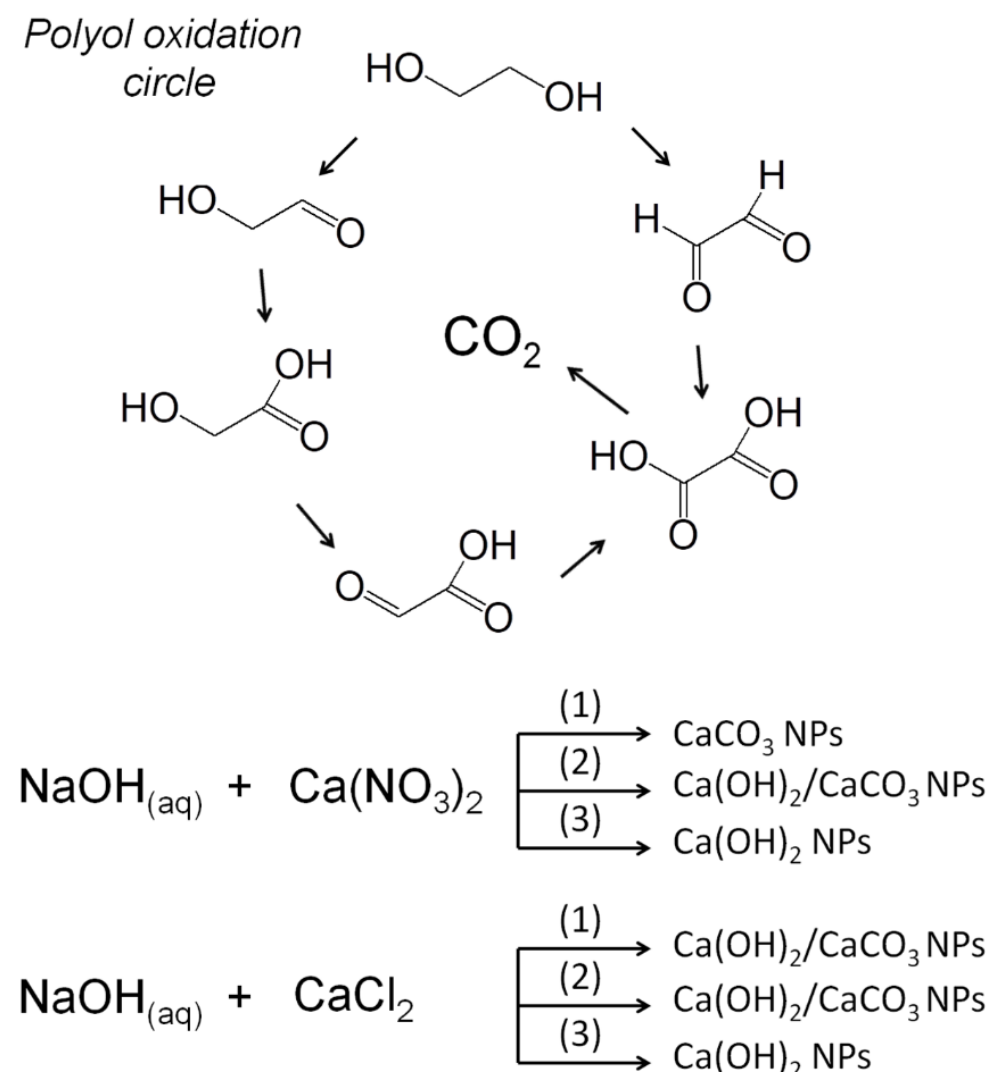

Scheme 1. System (structure \& chemical composition) and synthesis/fabrication.

Each structure, $\mathrm{Ca}(\mathrm{OH})_{2}, \mathrm{Ca}(\mathrm{OH})_{2} / \mathrm{CaCO}_{3} \& \mathrm{CaCO}_{3}$, was also identified and verified via FTIR spectroscopy (Fig. S2, SI). Characteristic bands appeared for each structure; strong, sharp bands at 3600 $\& 430 \mathrm{~cm}^{-1}$ corresponding to the $\mathrm{OH}$ and $\mathrm{Ca}-\mathrm{O}$ stretching of $\mathrm{Ca}(\mathrm{OH})_{2}$, respectively, and at $875 \& 710 \mathrm{~cm}^{-}$ ${ }^{1}$ corresponding to the $\mathrm{CO}_{3}$ group stretching mode of $\mathrm{CaCO}_{3}{ }^{35,48,51,64}$ Peaks in the $1500-1000 \mathrm{~cm}^{-1}$ area correspond to the organic coating.

All synthesized Ca-based NPs form stable aqueous suspensions. No sedimentation occurred in the time period of 96 hours indicating the stability of the suspensions. The hydrodynamic size and surface charge of CaN NPs (suspensions at neutral pH) stabilized by PG, TEG and PEG are $220 \mathrm{~nm}$ and $-11 \mathrm{mV}$, $132 \mathrm{~nm}$ and $-12 \mathrm{mV}, 190 \mathrm{~nm}$ and $-13 \mathrm{mV}$ respectively. CaN NPs DLS and $\zeta$-potential measurements are given in Figure S3 (SI) where only one peak is observed with small polydispersity indexs (pdi) that indicate 
the presence of monomodal size distribution, no significant aggregation and high colloidal stability. Each synthesized composition of Ca-based NPs is expected to adjust $\mathrm{pH}$ values. It is well known that, in water, $\mathrm{Ca}(\mathrm{OH})_{2}$ can produce $[\mathrm{OH}]^{-}$anions as well as that $\mathrm{CaCO}_{3}$ can produce $\left[\mathrm{CO}_{3}\right]^{2-}$ anions. The first type of ionic release is followed by $\mathrm{pH}$ raise while the second by $\mathrm{pH}$ drop and neutralizes acidic and alkaline soils, respectively. More specific, the ionic release of all NPs aqueous suspensions was unveiled through pHmetric measurements, shown in Figure 3. pH values for all NPs aqueous suspensions in two concentrations, 50 and $300 \mu \mathrm{g} / \mathrm{ml}$, and over four time periods, 24, 48, 72 and 92 hours, are presented. 

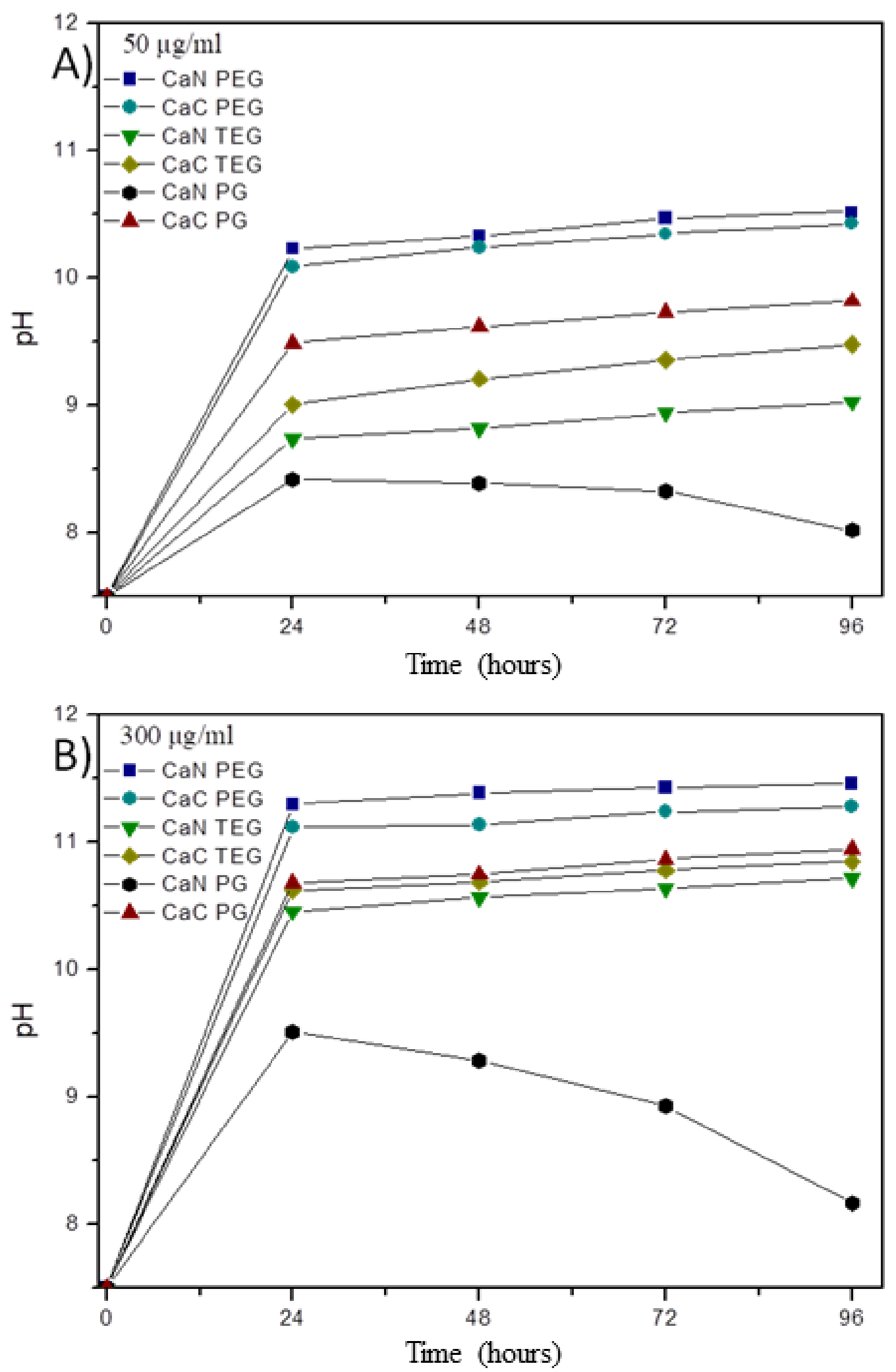

Figure 3. pH-metric measurements of $50 \mu \mathrm{g} / \mathrm{ml}$ (A) \& $300 \mu \mathrm{g} / \mathrm{ml}$ (B) aqueous suspensions of Ca-based NPs synthesized with PEG, TEG \& PG, $\mathrm{CaCl}_{2}(\mathrm{CaC}) \& \mathrm{Ca}\left(\mathrm{NO}_{3}\right)_{2}(\mathrm{CaN})$ precursors. 
$\mathrm{Ca}(\mathrm{OH})_{2} \mathrm{NPs}(\mathrm{CaN}$ PEG and CaC PEG) display a steady increase in $\mathrm{pH}$ values over time and the highest $\mathrm{pH}$ values amongst all NPs, while higher $\mathrm{pH}$ values were measured for NPs with the lower \% w/w of the organic coating (CaN PEG). $\mathrm{Ca}(\mathrm{OH})_{2} / \mathrm{CaCO}_{3} \mathrm{NPs}$ (CaN TEG, $\mathrm{CaC}$ TEG and $\mathrm{CaC}$ PG) demonstrate the same $\mathrm{pH}$ profile but with lower $\mathrm{pH}$ values, due to being mixtures which contain the $\mathrm{pH}$ reducing $\mathrm{CaCO}_{3}$ phase. However, all three NPs have significantly more than $50 \% \mathrm{w} / \mathrm{w}$ of $\mathrm{Ca}(\mathrm{OH})_{2}$ that overhauls the $\mathrm{pH}$ reducing ability of $\mathrm{CaCO}_{3}$. Differences in the $\mathrm{pH}$ values could be associated with the \%w/w structural composition of $\mathrm{Ca}(\mathrm{OH})_{2} / \mathrm{CaCO}_{3} \mathrm{NPs}$. Rapid changes in $\mathrm{pH}$ values could affect plants and microorganisms negatively. For this reason, a well-buffered soil is considered more desirable. ${ }^{17}$ While the $\mathrm{Ca}(\mathrm{OH})_{2} / \mathrm{CaCO}_{3}$ produced lower $\mathrm{pH}$ values, changes are not so rapid and can be desirable for second stage agriculture applications. In contrast, $\mathrm{CaCO}_{3} \mathrm{NPs}(\mathrm{CaN} \mathrm{PG})$ show a $\mathrm{pH}$ reduction over time, attributed to the acidity of $\left[\mathrm{CO}_{3}\right]^{2-}$ anions. The increase in 24 hours compared to the $\mathrm{pH}$ of the water $(\mathrm{pH}=7.5$, hour $=0)$ can be linked to the alkalinity of PG or partial hydrolysis of $\mathrm{Ca}^{2+}$. Based on the basic pOH equations, the ionic release at 96 hours were calculated at $8.6 \%$ for CaN PEG while others samples displayed non significant values (< $4 \%)$.

Morphological particle characteristics were investigated with electron microscopy. TEM images are shown in Figure 4 revealing hexagonal $\mathrm{Ca}(\mathrm{OH})_{2}$ portlandite NPs (CaN PEG) (Fig. 4.A) and rhombohedral $\mathrm{CaCO}_{3}$ nanocrystals (CaN PG) (Fig. 4.B). Counting over 100 particles provided TEM size and standard deviation of $16.5 \pm 0.15$ and $76.95 \pm 1.48 \mathrm{~nm}$ for $\mathrm{Ca}(\mathrm{OH})_{2}$ and $\mathrm{CaCO}_{3}$, respectively. Calculated values are in good agreement with crystallite size determined by XRD. For $\mathrm{Ca}(\mathrm{OH})_{2} \mathrm{NPs}$, pseudohexagonally plated crystalline features appear due to relatively small size of the NPs in contrast with already reported materials, while for $\mathrm{CaCO}_{3}$ truncated surfaces are observed. In general vacancies and truncated surfaces can be observed in both compositions, a desired characteristic for many calcium based applications. Figure S4 (SI) portrays the TEM image of $\mathrm{Ca}(\mathrm{OH})_{2} / \mathrm{CaCO}_{3} \mathrm{NPs}(\mathrm{CaN}$ TEG), where aggregation prevents the identification of distinct nanoparticles. However $\mathrm{Ca}(\mathrm{OH})_{2} / \mathrm{CaCO}_{3} \mathrm{NPs}$ appear as a uniform composition verifying their suggested core/shell morphology. 


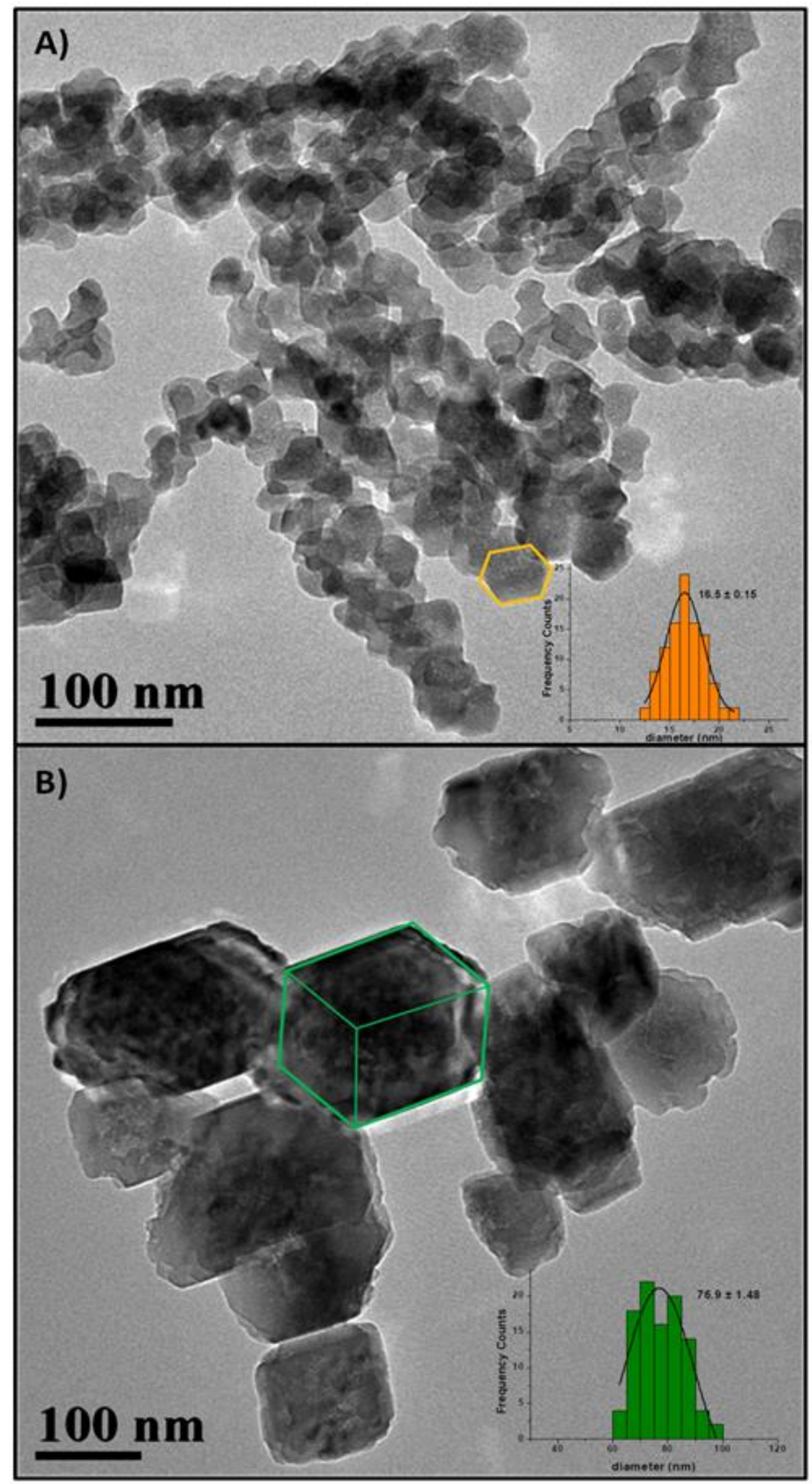


Figure 4. TEM images of (A) $\mathrm{Ca}(\mathrm{OH})_{2} \mathrm{NPs}(\mathrm{CaN} \mathrm{PEG})$ and (B) $\mathrm{CaCO}_{3} \mathrm{NPs}(\mathrm{CaN} \mathrm{PG})$ showing the crystal hexagonal and rhombohedral morphology, respectively.

\subsection{In vitro nematicidal activity of Ca-based NPS}

Amongst the produced samples, three significantly different formulations with almost the same crystallite size, $\mathrm{Ca}(\mathrm{OH})_{2}(\mathrm{CaN} \mathrm{PEG}), \mathrm{Ca}(\mathrm{OH})_{2} / \mathrm{CaCO}_{3}\left(\mathrm{CaN}\right.$ TEG) and $\mathrm{CaCO}_{3}(\mathrm{CaN} \mathrm{PG}) \mathrm{NPs}$, were evaluated as nematicidals. Two nematode Meloidogyne species (M. incognita and M. javanica) were chosen for the evaluation and were exposed to Ca-based NPs as well as $\mathrm{CaCl}_{2}$ (inorganic salt) for 24, 48, 72 and $96 \mathrm{~h}$. Estimation of the nematicidal activity of NPs was carried out by the means of optical imaging of juvenile nematodes (both $\mathrm{CaCl}_{2}$ and NPs' exposed cultures) where the assessment of the mobility of the nematodes revealed the action of NPs. Captions of nematode cultures (both control and NPs' exposed) can been seen in Figure 5. 
A)

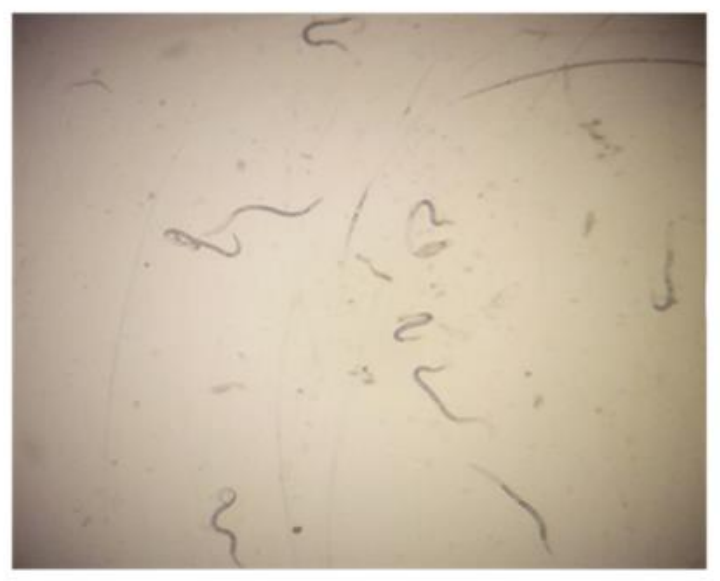

C)

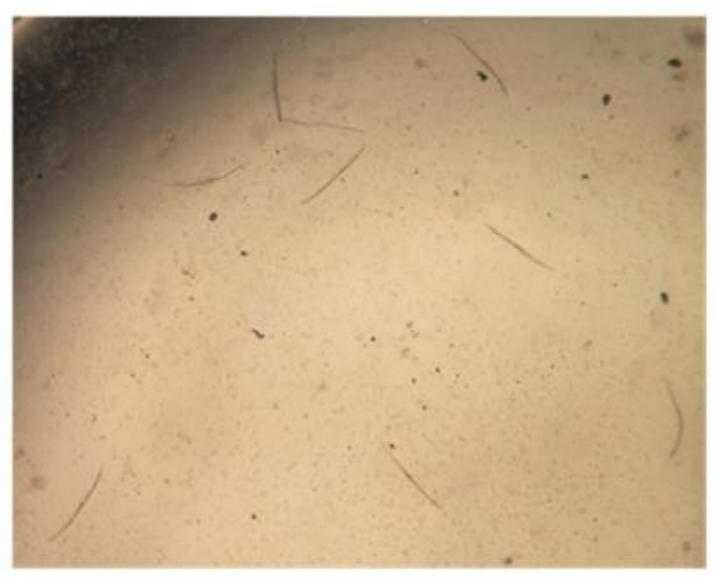

B)

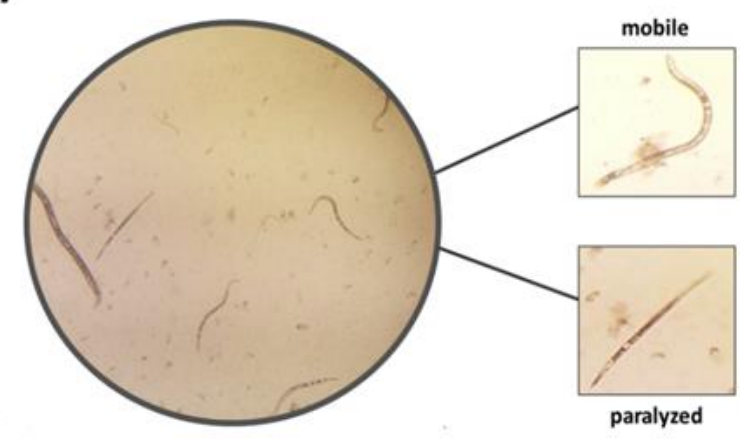

D)

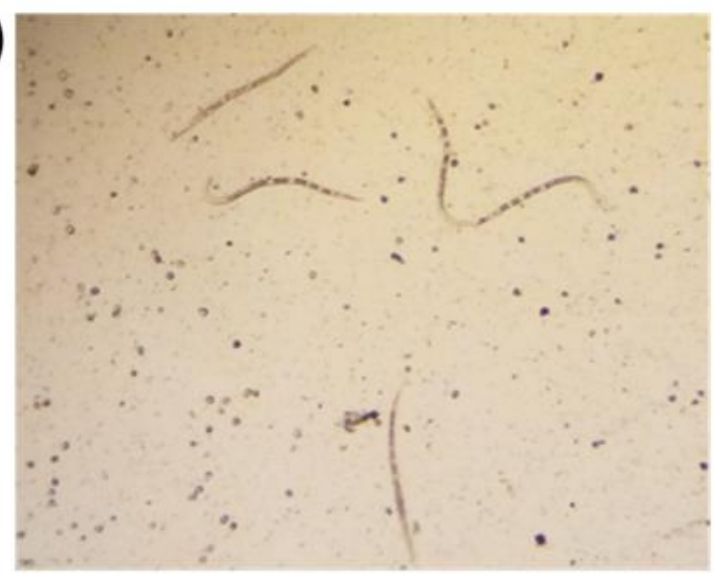

Figure 5. Optical microscope images (inverted microscope $\mathrm{x} 40)$ of nematodes (M. incognita) in control (A), after treatment with $\mathrm{Ca}(\mathrm{OH})_{2} / \mathrm{CaCO}_{3} \mathrm{NPs}(\mathrm{B}), \mathrm{Ca}(\mathrm{OH})_{2} \mathrm{NPs}(\mathrm{C})$ and $\mathrm{CaCO}_{3} \mathrm{NPs}(\mathrm{D})$ for 24 hours. Paralyzed nematodes can be spotted in the presence of all Ca-based NPs.

Nematodes in captions were ranked into two distinct categories: mobile or paralyzed. Control cultures contain only mobile juveniles (Fig. 5A) while paralyzed nematodes can be spotted in the presence of all Ca-based NPs (Fig. 5B-D), portraying their nematicidal activity. Dose responses curves for different aquatic suspensions of NPs in all time periods are given in Figure 6 for M. incognita and in Figure 7 for M. javanica. $\mathrm{EC}_{50}$ values are summed up in Table 2. 

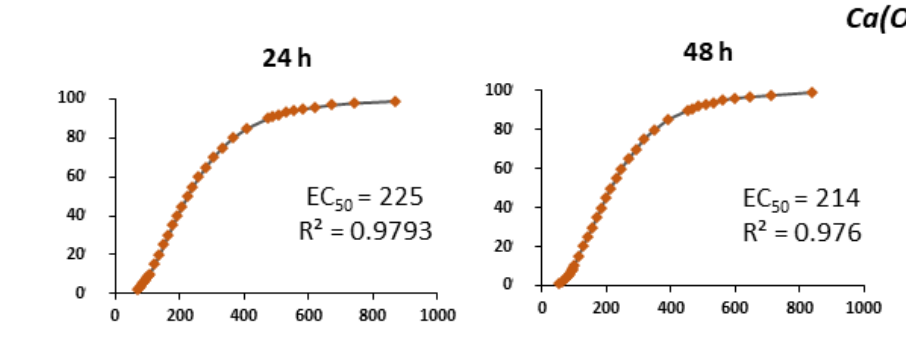

\section{$\mathrm{Ca}(\mathrm{OH})_{2} \mathrm{NPS}$}
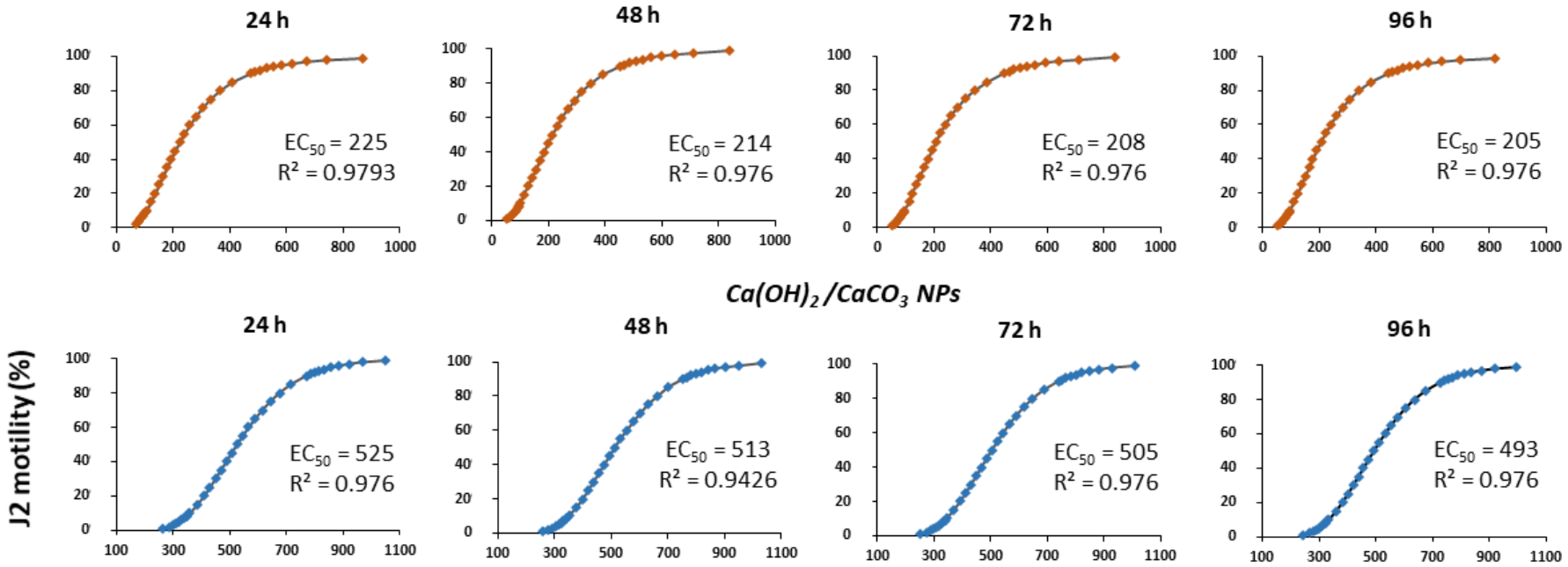

\section{$\mathrm{Ca}(\mathrm{OH})_{2} / \mathrm{CaCO}_{3} \mathrm{NPs}$}
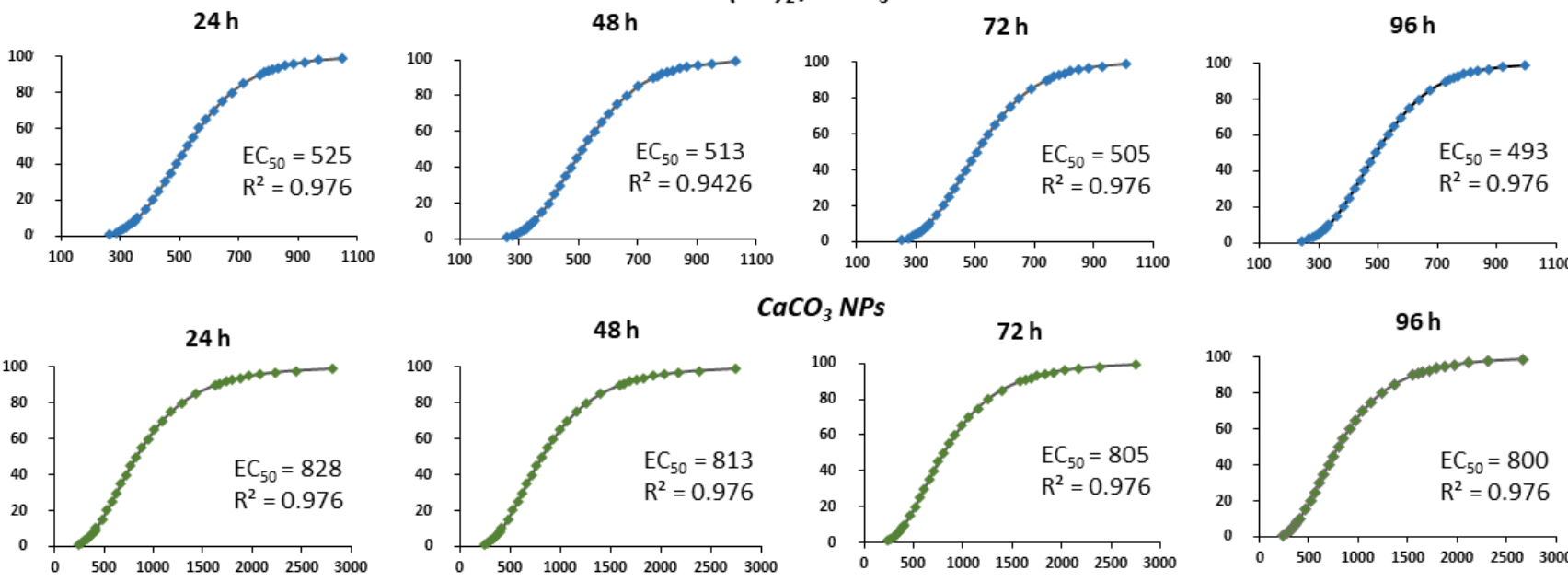

$\mathrm{CaCO}_{3} \mathrm{NPs}$
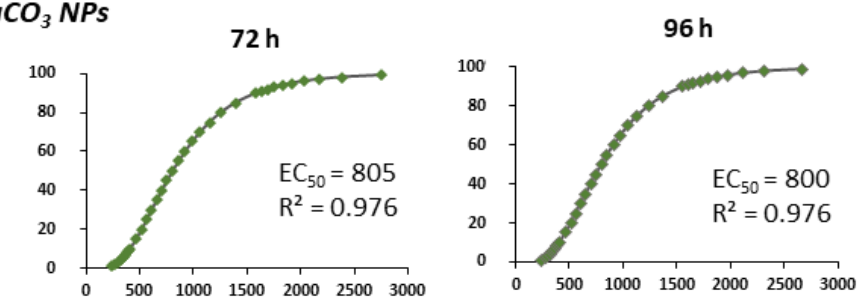

Ca- based nanoparticles concentration $(\mu \mathrm{g} / \mathrm{ml})$

Figure 6. Dose-response curves of Meloidogyne incognita paralysis following immersion in solutions of

Ca-based NPs for 24, 48, 72 and $96 \mathrm{~h}$. Each point represents the average $\%$ number of paralysed nematodes of six replications per treatment ( $\times 2$ experiment replications) after eliminating natural death/paralysis measured in the control.

It is lucid for the data that the nematicidal activity of evaluated Ca-based NPs follows the order $\mathrm{Ca}(\mathrm{OH})_{2}>\mathrm{Ca}(\mathrm{OH})_{2} / \mathrm{CaCO}_{3}>\mathrm{CaCO}_{3}$. The strongest activity against Meloidogyne incognita larvae was presented after $\mathrm{Ca}(\mathrm{OH})_{2} \mathrm{NPs}$ treatment with $\mathrm{EC}_{50 / 24 \mathrm{~h}}$ value $255 \mu \mathrm{g} / \mathrm{ml}$ followed by $\mathrm{Ca}(\mathrm{OH})_{2} / \mathrm{CaCO}_{3} \mathrm{NPs}$ with $525 \mu \mathrm{g} / \mathrm{ml}$ and $\mathrm{CaCO}_{3} \mathrm{NPs}$ with $828 \mu \mathrm{g} / \mathrm{ml}$. Fosthiazate, a commercial pesticide has been evaluated as a positive control with an $\mathrm{EC}_{50}$ of $20 \mu \mathrm{g} / \mathrm{ml}$. Although, $\mathrm{Ca}(\mathrm{OH})_{2} \mathrm{NPs}$ display a 10 fold increase in their $\mathrm{EC}_{50}$ when compared with Fosthiazate, the $\mathrm{EC}_{50 / 24 \mathrm{~h}}$ value of $255 \mu \mathrm{g} / \mathrm{ml}$ is still promising taking into account that commercial chemical pesticides are not environmental friendly and the goal is to be replaced by biocompatible materials. The same profile is observed in Meloidogyne javanica with a slightly lessened nematicidal activity, strongest activity in the presence of $\mathrm{Ca}(\mathrm{OH})_{2} \mathrm{NPs}$ with $\mathrm{EC}_{50 / 24 \mathrm{~h}}$ value of $311 \mu \mathrm{g} / \mathrm{ml}$, with $\mathrm{Ca}(\mathrm{OH})_{2} / \mathrm{CaCO}_{3} \mathrm{NPs}$ at $628 \mu \mathrm{g} / \mathrm{ml}$ and $\mathrm{CaCO}_{3} \mathrm{NPs}$ at $883 \mu \mathrm{g} / \mathrm{ml}$. In general, an expected dose response 
was monitored, while $\mathrm{EC}_{50}$ values increased to some extent over time but overall a stable nematicidal effect is presented.

Figure 7. Dose-response curves of Meloidogyne javanica paralysis following immersion in solutions of
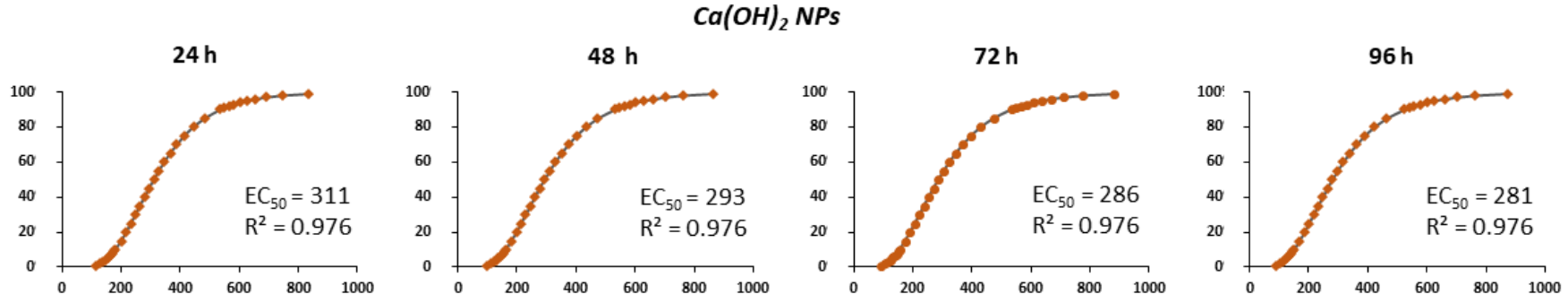

$\mathrm{Ca}(\mathrm{OH})_{2} / \mathrm{CaCO}_{3} \mathrm{NPs}$
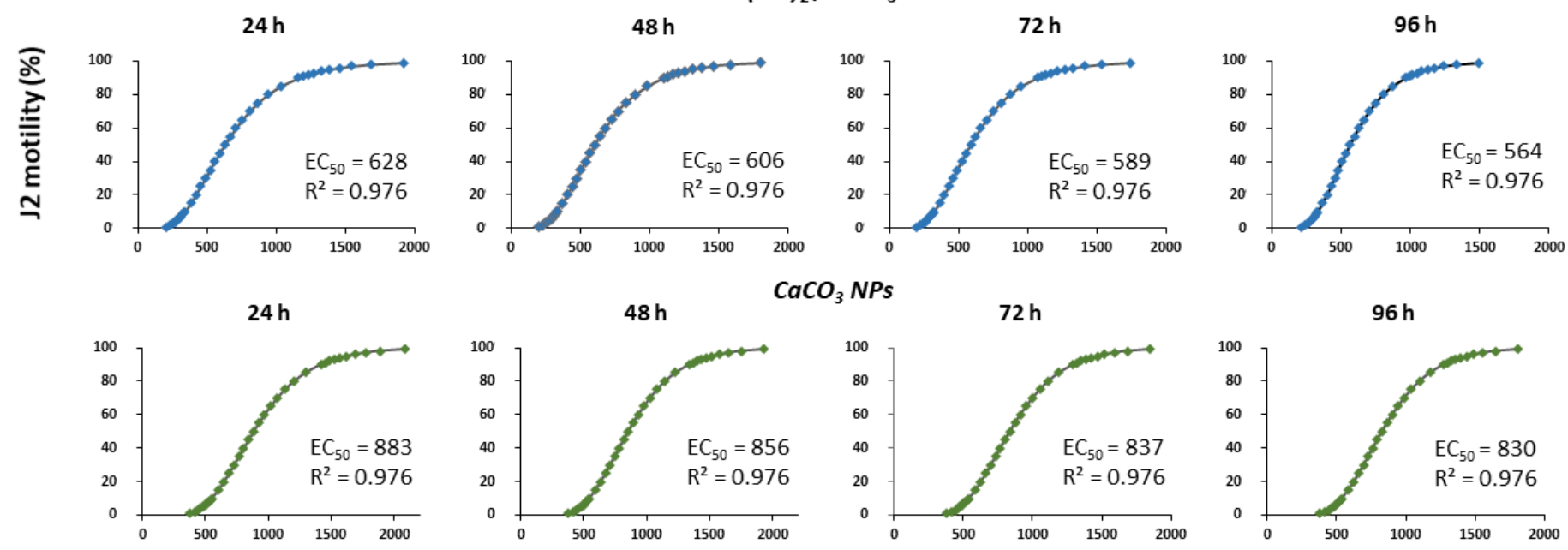

$\mathrm{CaCO}_{3} \mathrm{NPS}$
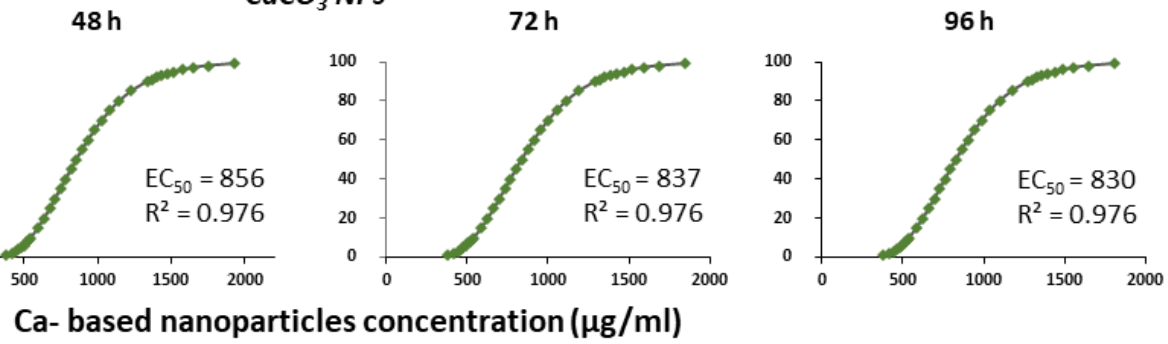

Ca-based NPs for 24, 48, 72 and $96 \mathrm{~h}$. Each point represents the average $\%$ number of paralysed nematodes of six replications per treatment $(\times 2$ experiment replications) after eliminating natural death/paralysis measured in the control.

Table 2. $\mathrm{EC}_{50}$ values of Ca-based NPs paralysis activity against Meloidogyne incognita, and Meloidogyne javanica calculated for $24,48,72$ and 96 hours immersion periods in test solutions. 


\begin{tabular}{|c|c|c|c|c|c|c|c|c|}
\hline \multirow{2}{*}{ Ca-based NPs } & \multicolumn{6}{|c|}{$\mathrm{EC}_{50}( \pm \mathrm{Std}$. Error) $(\mu \mathrm{g} / \mathrm{ml})$} \\
\cline { 2 - 9 } & $\mathbf{5}$ & \multicolumn{5}{c|}{ Meloidogyne javanica } \\
\cline { 2 - 9 } & $\mathbf{2 4}$ hours & $\mathbf{4 8}$ hours & $\mathbf{7 2}$ hours & $\mathbf{9 6}$ hours & $\mathbf{2 4}$ hours & $\mathbf{4 8}$ hours & $\mathbf{7 2}$ hours & $\mathbf{9 6}$ hours \\
\hline $\mathrm{Ca}(\mathrm{OH})_{2}$ & $225 \pm 0.2$ & $214 \pm 0.24$ & $208 \pm 0.22$ & $205 \pm 0.23$ & $311 \pm 0.1$ & $293 \pm 0.2$ & $286 \pm 0.2$ & $281 \pm 0.2$ \\
\hline $\mathrm{Ca}(\mathrm{OH})_{2} / \mathrm{CaCO}_{3}$ & $525 \pm 0.3$ & $513 \pm 0.32$ & $505 \pm 0.3$ & $493 \pm 0.4$ & $628 \pm 0.3$ & $606 \pm 0.4$ & $589 \pm 0.3$ & $564 \pm 0.4$ \\
\hline $\mathrm{CaCO}_{3}$ & $828 \pm 0.4$ & $813 \pm 0.42$ & $805 \pm 0.3$ & $800 \pm 0.4$ & $883 \pm 0.3$ & $856 \pm 0.3$ & $837 \pm 0.2$ & $830 \pm 0.2$ \\
\hline
\end{tabular}

$*$ Statistical $\mathrm{R}^{2}$ values are $\cong 0.98$ for all $\mathrm{EC}_{50}$ values.

$\mathrm{A} \mathrm{CaCl}_{2}$ solution at concentrations of $50,100,200,400$ and $800 \mathrm{mg} / \mathrm{ml}$ was also evaluated and did not have an effect in both of Meloidogyne species. Similar result was also reported previously ${ }^{65}$ and was verified in the current study. Moreover, it confirms that any $\mathrm{Ca}^{2+}$ ions released from NPs would not have an effect in their nematicidal activity of Ca NPs. It is appealing that each different structure/formulation, $\mathrm{Ca}(\mathrm{OH})_{2}, \mathrm{Ca}(\mathrm{OH})_{2} / \mathrm{CaCO}_{3}$ and $\mathrm{CaCO}_{3} \mathrm{NPs}$, displayed notably dissimilar nematicidal activity. In that manner, from this initial assessment nematicidal activity of Ca-based NPs can be linked to the structure and composition unveiling that $\mathrm{Ca}(\mathrm{OH})_{2}$ is the most effective nematicidal agent. However, size effects cannot be excluded in case of $\mathrm{CaCO}_{3} \mathrm{NPs}(77 \mathrm{~nm})$ and $\mathrm{Ca}(\mathrm{OH})_{2}(16.5 \mathrm{~nm})$ as the $\mathrm{EC}_{50}$ values are 4 fold, respectively. Nonetheless, when $\mathrm{Ca}(\mathrm{OH})_{2}$ and $\mathrm{Ca}(\mathrm{OH})_{2} / \mathrm{CaCO}_{3}$ with very similar sizes compared, nematicidal effect appears to be boosted and favors the hypothesis that $[\mathrm{OH}]^{-}$anions play a crucial role in the nematicidal activity. It is important to note that there is no effect on nematodes of bulk $\mathrm{Ca}(\mathrm{OH})_{2} .{ }^{66} \mathrm{The}$ action of $[\mathrm{OH}]^{-}$anions can be correlated to oxidative stress induced to the nematodes as previously reported ${ }^{67}$ while transport of anions happens through the ion canals of the nematodes. Based on the nematicidal and pH experiments, $\mathrm{Ca}(\mathrm{OH})_{2}$ is proposed as the best nematicidal agent against $M$. incognita and $M$. javanica, $\mathrm{CaCO}_{3}$ as the most stable $\mathrm{pH}$ adjuster while the combined $\mathrm{Ca}(\mathrm{OH})_{2} / \mathrm{CaCO}_{3} \mathrm{NPs}$ appear to have an intermediate action.

\section{Conclusions}


Root knot nematodes are undoubtedly a main problem of the agricultural sector and striving to develop effective control agents to deal with the issue is urgent and considerable efforts are needed. Inorganic/organic hybrid nanoparticle formulations appear as strongly promising materials among other novel substances under evaluation as economically sustainable, environmentally sound, highly stable and biocompatible alternatives, with control over the release of active components both for pest control and soil and plant boost. Amongst inorganic materials, Ca-based nanoparticles should be viewed as a biocompatible material with dual functions, able to boost plant growth via raising soil $\mathrm{pH}$ and protect the plant from microorganisms and pests. Herein, a simple synthetic process was developed to provide selectivity over the structure of the as-produced Ca-based nanomaterial, $\mathrm{Ca}(\mathrm{OH})_{2}, \mathrm{Ca}(\mathrm{OH})_{2} / \mathrm{CaCO}_{3}$ and $\mathrm{CaCO}_{3}$, by using chemical protocols involving proper polyol and precursor combinations. The structure-activity relationship shows that structural alterations among used compounds induced dissimilar nematicidal effects. Nonetheless, given that each structure is linked with a diverse $\mathrm{pH}$ adjustment as well as that these changes in $\mathrm{pH}$ can also affect plant growth, depending on the type of crop the appropriate composition can be chosen when either stable $\mathrm{pH}$ changes and/or strong nematicidal actions are required. The biological activity shows a concentration-dependent function. $\mathrm{Ca}(\mathrm{OH})_{2} \mathrm{NPs}$ proved to be more efficient than $\mathrm{Ca}(\mathrm{OH})_{2} / \mathrm{CaCO}_{3}$ against M. incognita and $M$. javanica in vitro. However, the multimodal action of $\mathrm{Ca}(\mathrm{OH})_{2} / \mathrm{CaCO}_{3}$ could rise as the most appealing two way nanofertilizer. On the other hand, $\mathrm{CaCO}_{3}$ exhibited the lowest $\mathrm{EC}_{50}$ values, but could be utilized for its soil $\mathrm{pH}$ lowering activity. These results encourage the research to proceed in invivo experiments and examine further the multimodal activity of Ca-based nanoparticles in boosting crop growth and tackle the occurrence of phyto-parasites and phyto-pathogenic microorganisms.

\section{Supporting Information}

Additional data with X-ray diffractograms, FTIR spectra, DLS measurements and TEM images of Ca-based nanoparticles. This material is available free of charge via the Internet. 


\section{Conflict of interest}

The authors declare that there are no conflicts of interest

\section{Acknowledgment}

This research was not funded by any external sources of funding to the authors. 


\section{REFERENCES}

1) Guével, X. Overview of Inorganic Nanoparticles for Food Science Applications. Nanotechnology in Agriculture and Food Science. 2017, pp.197-208.

2) Chen, H. and Yada, Y. R. Nanotechnologies in agriculture: New tools for sustainable development. Trends in Food Sc \& Techn. 2011, 22(11): 585-594.

3) Roohinejad, S and Greiner, R. Nanoscience: Relevance for Agriculture and Food Sector. Nanotechnology in Agriculture and Food Science. 2017, 1th Edition, pp. 15-31.

4) Chhipa, H. and Joshi, P. Nanofertilisers, Nanopesticides and Nanosensors in Agriculture. Nanosc Food Agr. 2016, Chapter 9, p254.

5) Mazzaglia, A.; Fortunati, E.; Kenny, J. M.; Torre, L.; Balestra, G. M. Nanomaterials in Plant Protection. Nanotech Agr Food Sc. 2017, Chapter 7, p.115.

6) Fleming T. R.; Maule A. G.; Fleming C. C. Chemosensory Responses of Plant Parasitic Nematodes to Selected Phytochemicals Reveal Long-Term Habituation Traits. J Nematol. 2017, 49(4):462471.

7) Jones, J. T.; Haegeman, A.; Danchin, E. G. J.; Gaur, H. S.; Heilder, J.; Jones, G. K.; Kikuchi, T.; Manzanilla-Lopez, R.; Palomaers-Rius, J. E.; Wim, M. L.; Esmael, W. M. L.; Perry, R. N. Top 10 plant-parasitic nematodes in molecular plant pathology (Review). Mol Plant Pathol. 2013, 14(9), 946-961.

8) Ntalli N. G. and Caboni P. Botanical Nematicides: A Review. J. Agric. Food Chem. 2012, 60, 9929-9940.

9) Servin, A.; Elmer, W.; Mukherjee, A.; Torre-Roche, R.; Hamdi, H.; White, C. J.; Dimkpa, C. A review of the use of engineered nanomaterials to suppress plant disease and enhance crop yield. $J$ Nanopart Res. 2015, 17(92) 1-21.

10) Ma, H.; Bertsch, M. P.; Glenn, C.T.; Kabengi, J. N.; Williams, L. P. Toxicity of manufactured Zinc oxide Nanoparticles in the nematode Caenorhabditis elegans. Env Toxic Chem. 2009, 28(6): 1324 1330. 
11) Gupta, S.; Kushwah, T.; Vishwakarma, A.; Yadav, S. Optimization of ZnO-NPs to Investigate Their Safe Application by Assessing Their Effect on Soil Nematode Caenorhabditis elegans. Nanoscale Res Lett. 2015, 10(1): 1010.

12) Wang, H.; Wick, L. R.; Xing, B. Toxicity of nanoparticulate and bulk $\mathrm{ZnO}, \mathrm{Al}_{2} \mathrm{O}_{3}$ and $\mathrm{TiO}_{2}$ to the nematode Caenorhabditis elegans. Environ Pollut. 2009, 157(4): 1171-1177.

13) Cromwell, A.W.; Yang, J.; Starr, L.J.; Jo, Y-K. Nematicidal Effects of Silver Nanoparticles on Root-knot Nematode in Bermudagrass. J Nematol. 2014, 46(3): 261-266.

14) Hadi, R.M and Karimi, N. The Role of Calcium in Plants Salt Tolerance. J Plant Nut. 2012, 35(13): 2037-2054.

15) Waraich, E.A.; Ahmad, R.; Halim, A.; Aziz, T. Alleviation of temperature stress by nutrient management in crop plants: a review. J Soil Sci. Plant Nutr. 2012, 12(2): 221-244.

16) Robertson, D. Modulating Plant calcium for Better Nutrition and Stress Tolerance: Review. ISRN Botany. 2013, 22: 1-22.

17) Bloom, S.; Brady, J.A.; Langer, A.G. Calcium metabolism and active tension in mechanically disaggregated heart muscle. J molec cellul Card. 1974, 6(2): 137-147.

18) Liu, R. and Lal, R., Potentials of engineered nanoparticles as fertilizers for increasing agronomic productions. Sci Total Environ. 2015, 1(9): 514-539.

19) Hua, X.; Yingan, L.; Hongjun, Z.; Xinhua, Z.; Huayao, C. Preparation of chlorpyrifos/calcium carbonate composite microsphere and their sustained release property. New Chem Mater. 2016,17(6): 8403-8408.

20) Karthik, K.; Dhanuskodi, S.; Gobinath, C.; Prabukumar, S.; Sivaramakrishnan, S. Dielectric and antibacterial studies of microwave assisted calcium hydroxide nanoparticles. J Mater Sci: Mater Electron. 2017, 28(21): 16509-16518.

21) Siqueira, J.F.Jr. and Lopes, H.P. Mechanisms of antimicrobial activity of calcium hydroxide: a critical review. Int Endod J. 1999, 32(5): 361-369.

22) Giannousi, K.; Avramidis, I.; Dendrinou-Samara, C. Synthesis, characterization and evaluation of copper based nanoparticles as agrochemicals against Phytophthora infestans. RSC Adv. 2013, 3, $21743-21752$. 
23) Giannousi, K.; Sarafidis, G.; Mourdikoudis, S.; Pantazaki, A.; Dendrinou-Samara, C. Selective synthesis of $\mathrm{Cu}_{2} \mathrm{O}$ and $\mathrm{Cu} / \mathrm{Cu}_{2} \mathrm{O}$ NPs: antifungal activity to yeast Saccharomyces cerevisiae and DNA interaction. Inorg Chem. 2014a, 53, 9657-9666.

24) Giannousi, K.; Lafazanis, K.; Arvanitidis, J.; Pantazaki, A.; Dendrinou-Samara, C. Hydrothermal synthesis of copper based nanoparticles: Antimicrobial screening and interaction with DNA. J Inorg Biochem. 2014b, 133, 24-32.

25) Giannousi, K.; Menelaou, M.; Arvanitidis, J.; Angelakeris, M.; Pantazaki, A.; Dendrinou-Samara, C., Hetero-nanocomposites of magnetic and antifungal nanoparticles as a platform for magnetomechanical stress induction in Saccharomyces cerevisiae. J Mater Chem B 3. 2015, 53415351.

26) Antonoglou, O.; Giannousi, K.; Arvanitidis, J.; Mourdikoudis, S.; Pantazaki, A.; DendrinouSamara, C. Elucidation of one step synthesis of PEGylated CuFe bimetallic nanoparticles. Antimicrobial activity of CuFe@PEG vs Cu@PEG. J. Inorg Biochem. 2017, 177, 159-170.

27) Antonoglou, O.; Moustaka, J.; Adamakis, S.I.-D.; Sperdouli, I.; Pantazaki, A.; Moustakas, M.; Dendrinou-Samara, C. Nanobrass CuZn Nanoparticles as Foliar Spray Nonphytotoxic Fungicides. ACS Appl Mater Interf. 2018, 11, 4450-4461.

28) Ntalli, G.N.; Ferrari, F.; Giannakou, I.; Menkissoglu-Spiroudi, U. Synergistic and antagonistic interactions of terpenes against Meloidogyne incognita and the nematicidal activity of essential oils from seven plants indigenous to Greece. Pest Manag Sc. 2011, 67 (3): 341-351.

29) Ntalli, N.; Menkissoglu-Spiroudi, U.; Giannakou, O.I.; Prophetou-Athanasiadou, A.D. Efficacy evaluation of a neem (Azadirachta indica A. Juss) formulation against root-knot nematodes Meloidogyne incognita. Crop Prot. 2009, 28: 489-494.

30) Ntalli, G.N.; Ferrari, F.; Giannakou, I.; Menkissoglu-Spiroudi, U. Phytochemistry and Nematicidal Activity of the Essential Oils from 8 Greek Lamiaceae Aromatic Plants and 13 Terpene Components. J Agric Food Chem. 2010, 58 (13): 7856-7863.

31) Ntalli, N.G.; Oplos, Ch.; Michailidis, M.; Thanasenaris, A.; Kontea.; Pierluigi, C.; MenkissogluSpiroudi, U.; Tsiropoulos, N. G.; Adamski, Z. Strong synergistic activity and egg hatch inhibition by (E,E)-2,4-decadienal and (E)-2-decenal in Meloidogyne species. J Pest Sci. 2016, 89, 565-579. 
32) Aissani, N.; Balti, R.; Seba, H. Potent nematicidal activity of phenolic derivatives on Meloidogyne incognita. J Helmint. 2018, 92(6): 668-673.

33) Puntener, W. Manual for field trials in plant protection. 1981, $2^{\text {nd }} e d n$, p. 205.

34) Seefeldt, S.S.; Jensen, J.E.; Fuerst, E.P. Log-logistic analysis of herbicide rate response relationships. Weed Techn. 1995, 9, 218-227.

35) Rodriguez-Navarro, C.; Ruiz-Agudo, E.; Ortega-Huertas, M.; Hansen, E. Nanostructure and irreversible colloidal behavior of $\mathrm{Ca}(\mathrm{OH})_{2}$ : implications in cultural heritage conservation. Langmuir. 2005, 22;21(24): 10948-57.

36) Arandi Z. N. Calcium hydroxide liners: a literature review Clinical, Cosm \& Invest Dent. 2017, 9 , $67-72$.

37) Dow, C.; Glasser, P.F. Calcium carbonate efflorescence on Portland cement and building materials. Cem Concr Res. 2003, 33, 147-154.

38) Rao, K.J.; Vaidhyanathan, B.; Ganguli, M.; Ramakrishnan, P.A. Synthesis of inorganic solids using microwaves. Chem Mater. 1999, 11, 882-895.

39) Teichert, J.; Doert, T.; Ruck, M. Mechanisms of the polyol reduction of copper(II) salts depending on the anion type and diol chain length. Dalton Trans. 2018, 47, 14085-14093.

40) Dong, H.; Chen, Y.C.; Feldmann, C. Polyol synthesis of nanoparticles: status and options regarding metals, oxides, chalcogenides, and non-metal elements. Green Chem. 2015a, 17, 4107-4132.

41) Dong, H.; Roming, M.; Feldmann, C.; Unexpected Fluorescence of Polyols and PEGylated Nanoparticles Derived from Carbon Dot Formation. Part. Syst. Charact. 2015b, 32, 467-475.

42) Biacchi, A.J.; Schaak, R.E. The solvent matters: Kinetic versus thermodynamic shape control in the polyol synthesis of rhodium nanoparticles. ACS Nano. 2011, 5, 8089-8099.

43) Carroll, J.K.; Ulises-Reveles, J.; Shultz, D.M.; Khanna, N.S.; Carpenter, E.E. Preparation of Elemental $\mathrm{Cu}$ and Ni Nanoparticles by the Polyol Method: An Experimental and Theoretical Approach. J Phys. Chem C. 2011, 115, 2656-2664.

44) Caizer, C.; Ştefănescu, M. Synthesis and Characterization of Copper Substituted Nickel NanoFerrites by Citrate-Gel Technique. J Phys D: App. Phys. 2002, 35, 3035-3040. 
45) Ştefănescu, M.; Stoia, M.; Ştefănescu, O.; Barvinshci, P. The Interaction Between TEOS and Some Polyols. J Therm Anal Calorim. 2007, 88, 459-464.

46) Vamvakidis, K. Katsikini, M.; Vourlias, G.; Angelakeris, M.; Paloura, C.E.; Dendrinou-Samara, C. Composition and hydrophilicity control of Mn-doped ferrite (MnxFe3-xO4) nanoparticles induced by polyol differentiation. Dalton Trans. 2015, 44, 5396-5406.

47) Zavarzin, A.G. Microbial Geochemical Calcium Cycle: review. Microbiology. 2002, 71(1): 1-17, $5-22$.

48) Aniruddha, S.; Soumik, P.; Chandan, K.G.; Manjima, B.; Jiten, G.; Awadesh, K.M.; Arjun, D.; Anoop K.M. ROS mediated high anti-bacterial efficacy of strain tolerant layered phase pure nanocalcium hydroxide. J Mech Behav Biomed Mater. 2017, 72, 110-128.

49) Alavi, A.M. and Morsali, A. Ultrasonic-assisted synthesis of $\mathrm{Ca}(\mathrm{OH})_{2}$ and $\mathrm{CaO}$ nanostructures. J Exper Nanosc. 2010, 5(2): 93-105.

50) Momenian, R.H.; Gholamrezaei, S.; Salavati-Niasari, M.; Pedram, B.; Farhang, M.; Ghanbari, D. Sonochemical Synthesis and Photocatalytic Properties of Metal Hydroxide and Carbonate (M:Mg, Ca, Sr or Ba). Nanoparticles J Cluster Sci. 2013, 24(4): pp 1031-1042.

51) Roy, A. and Bhattacharya, J. Microwave-Assisted synthesis and characterization of $\mathrm{CaO}$ Nanoparticles. Inter J Nanosc. 2011, 10(3): 413-418.

52) Poggi, G.; Toccafondi, N.; Melita, N.L.; Knowles, C.J.; Bozec, L.; Giorgi, R.; Baglioni, P. Calcium hydroxide nanoparticles for the conservation of cultural heritage: New formulations for the deacidification of cellulose-based artifacts. Appl Phys A. 2014, 114(3): 685-693.

53) Darroudi, M.; Bagherpour, M.; Hosseini, A.H.; Ebrahimi, M. Biopolymer-assisted green synthesis and characterization of calcium hydroxide nanoparticles. Ceram Intern. 2016, 42(3): 3816-3819.

54) Babou-Kammoe, R.; Hamoudi, S.; Larachi, F; Belkacemi, K. Synthesis of $\mathrm{CaCO}_{3}$ nanoparticles by controlled precipitation of saturated carbonate and calcium nitrate aqueous solutions. Can J Chem Engin. 2012, 9999: 1-8.

55) Casanova, H and Higuita, P.L. Synthesis of calcium carbonate nanoparticles by reactive precipitation using a high pressure jet homogenizer. Chem Eng J. 2011, 175(15): 569-578. 
56) Biradar, S.; Ravichandran, P.; Gopikrishnan, R.; Goornavar, V.; Hall, C.J.; Ramesh, V.; Baluchamy, S.; Jeffers, B. R.; Ramesh, T. G. Calcium Carbonate Nanoparticles: Synthesis, Characterization and Biocompatibility. J Nanosci Nanotechnol. 2011, 11(8): 6868-6874.

57) Zhao, L.; Zhang, Y.; Miao, Y.; Nie, L. Controlled synthesis, characterization and application of hydrophobic calcium carbonate nanoparticles in PVC. Pow Tech. 2016, 288, 184-190.

58) He, M.; Eric, F.; Yanmin, W.; Yuexin, H. Ultrasonication-Assisted synthesis of calcium carbonate nanoparticles. Chem Engin Com. 2005, 192(11): 1468-1481.

59) Mishra, S.; Sonawane, S.; Chitodkar, V. Comparative study on improvement in mechanical and flame retarding properties of epoxy- $\mathrm{CaCO}_{3}$ nano and commercial composites. Polymer-Plastics Techn \& Engin. 2005a, 44(3): 463-473.

60) Mishra, S.; Sonawane, H. S.; Singh, P. R. Studies on characterization of nano $\mathrm{CaCO}_{3}$ prepared by the in situ deposition technique and its application in PP-nano $\mathrm{CaCO}_{3}$ composites. J Polymer Scien Part B: Polymer Physics. 2005b. 43(1): 107-113.

61) Song, M.H.; Anjum, H.D.; Sougrat. R.; Hedhili, N.M.; Khashab. M.N. Hollow Au@Pd and Au@Pt core-shell nanoparticles as electrocatalysts for ethanol oxidation reactions. J Mater Chem. 2012, 48(22): 25003-25010.

62) Nekhamanuraka B.; Patanathabutr, P.; Hongsriphan, N. The influence of micro-/nano-CaCO 3 on thermal stability and melt rheology behavior of poly(lactic acid). Energ Proc. 2014, 56, 118-128.

63) Shen, L.; Laibinis, E.P.; Hatton, A.T. Bilayer Surfactant Stabilized Magnetic Fluids: Synthesis and Interactions at Interfaces. Langmuir. 1999, 15, 447-453.

64) Salvadori, B. and Dei, L. Synthesis of $\mathrm{Ca}(\mathrm{OH})_{2}$ Nanoparticles from Diols. Langmuir. 2001, 17, $2371-2374$.

65) Thurston, G.D., Gorczynski, J.E.Jr.; Currie, J.H.; He, D.; Ito, K.; Kipfner, J.; Waldman, J.; Lioy, P.J.; Lippmann, M. The nature and origins of acid summer haze air pollution in metropolitan Toronto, Ontario. Envir Res. 1994, 65, 254-270.

66) Meyer, F.L.S.; Zasada, A. I.; Tenuta, M; Roberts, P.D. Application of a Biosolid Soil Amendment, Calcium Hydroxide, and Streptomyces for Management of Root-knot Nematode on Cantaloupe. HortTechnology 2005.15(3): 635-641. 
67) Wang, D., Nanotoxicology in Caenorhabditis elegans. Chapter 5. Physicochemical Basis for Nanotoxicity Formation. 2018, pp 76-77.

68) Chakrabarti, U., and Mishra, S.D. Evaluation of Biochemical parameters for screening resistance of chickpea cultivars against Meloidogyne incognita. Indian J. Nematol. 2002, 32(1): 26-29.

69) Meyer, L.F. S.; Zasada, A. I.; Tenuta, M.; Roberts, P. D. Application of a Biosolid Soil Amendment, Calcium Hydroxide, and Streptomyces for Management of Root-knot Nematode on Cantaloupe. HortTechnology. 2005, 15(3): 635-641.

70) Faske, R. T. and Hurd, K. Sensitivity of Meloidogyne incognita and Rotylenchulus reniformis to Fluopyram. J Nematol. 2015, 47(4): 316-321. 


\section{Table of Contents}

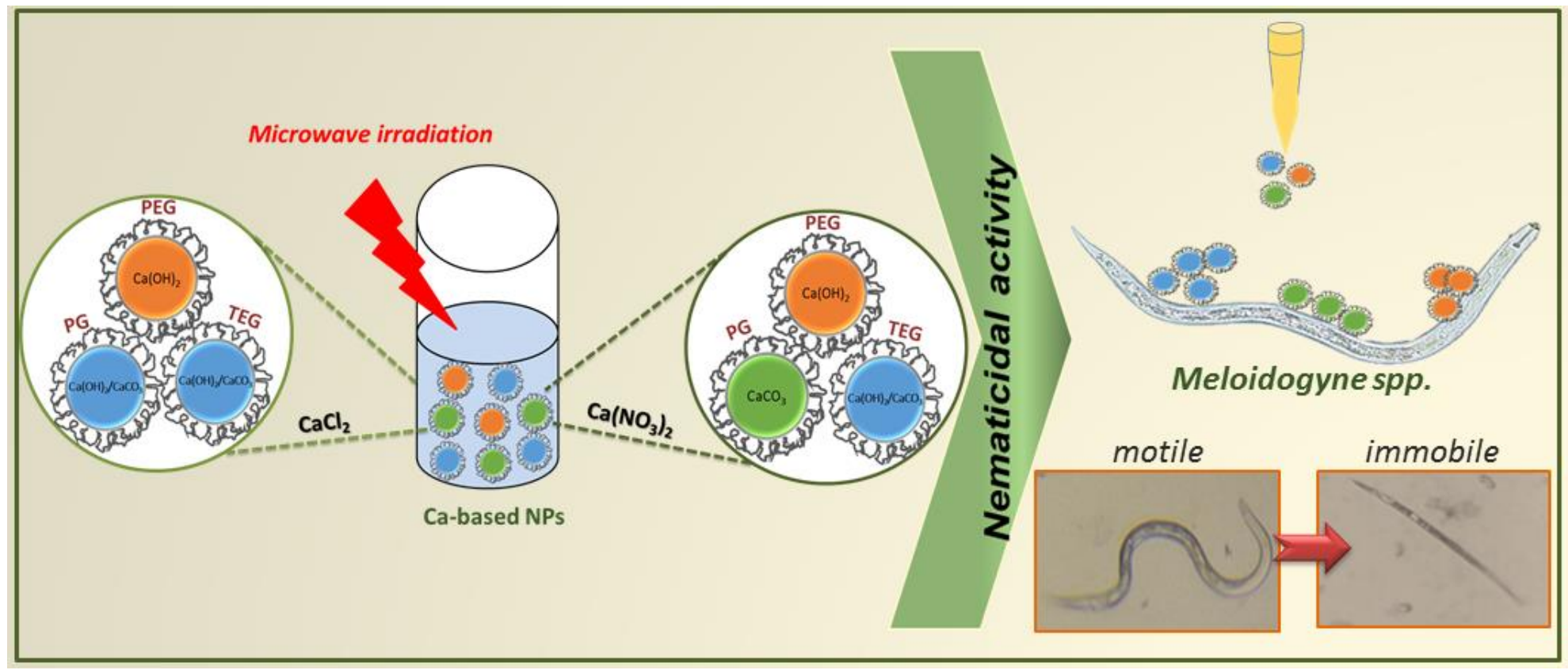

